\title{
The Effect of Oxygen on Nonthermal-Plasma Reactions of Nitrogen Oxides in Nitrogen
}

\author{
Morris D. Argyle \\ mdargyle@byu.edu
}

Gui-Bing Zhao

S.V.B. Janardhan Garikipati

Xudong $\mathrm{Hu}$

Maciej Radosz

Follow this and additional works at: https://scholarsarchive.byu.edu/facpub

Part of the Chemical Engineering Commons

\section{Original Publication Citation}

G.B. Zhao, S.V.B.J. Garikipati, X. Hu, M.D. Argyle, M. Radosz, "The Effect of Oxygen on Nonthermal-Plasma Reactions of Dilute Nitrogen Oxide Mistures in N2." AIChE Journal, 51, 1813-1821, 25.

\section{BYU ScholarsArchive Citation}

Argyle, Morris D.; Zhao, Gui-Bing; Garikipati, S.V.B. Janardhan; Hu, Xudong; and Radosz, Maciej, "The Effect of Oxygen on Nonthermal-Plasma Reactions of Nitrogen Oxides in Nitrogen" (2005). Faculty Publications. 379.

https://scholarsarchive.byu.edu/facpub/379

This Peer-Reviewed Article is brought to you for free and open access by BYU ScholarsArchive. It has been accepted for inclusion in Faculty Publications by an authorized administrator of BYU ScholarsArchive. For more information, please contact ellen_amatangelo@byu.edu. 


\title{
The Effect of Oxygen on Nonthermal-Plasma Reactions of Nitrogen Oxides in Nitrogen
}

\author{
Gui-Bing Zhao, S.V.B.Janardhan Garikipati, Xudong Hu, Morris D. Argyle, Maciej Radosz ${ }^{*}$ \\ Department of Chemical \& Petroleum Engineering, University of Wyoming, Laramie, WY \\ 82071-3295, USA
}

\begin{abstract}
NO is mainly converted to $\mathrm{NO}_{2}$ by chemical oxidation in the presence of oxygen. Initial selectivity analysis shows that three electron collision reactions are important for $\mathrm{NO}_{\mathrm{x}}$ evolution in $\mathrm{O}_{2} / \mathrm{N}_{2}$. The rate constants of these reactions decrease with increasing oxygen concentration. This is because oxygen is electronegative and hence reduces electron concentration. The rate constant of $\mathrm{O}_{2}$ dissociation by electron collision reaction is almost two orders of magnitude higher than that of $\mathrm{N}_{2}$ dissociation. NO formation occurs predominantly through $\mathrm{N}\left({ }^{2} \mathrm{D}\right)+\mathrm{O}_{2} \rightarrow$ $\mathrm{NO}+\mathrm{O}$. The critical oxygen concentration, defined as the concentration above which the $\mathrm{NO}_{\mathrm{x}}$ formation rate exceeds the $\mathrm{NO}_{\mathrm{x}}$ decomposition rate, increases with increasing the initial $\mathrm{NO}$ concentration.
\end{abstract}

Submitted to AIChE $J$

* Corresponding author. E-mail: radosz@uwyo.edu, tel: 307-766-2500, fax: 307-766-6777 


\section{Introduction}

The removal of nitrogen oxides $\left(\mathrm{NO}_{\mathrm{x}}\right)$ from combustion exhaust streams has become an important international technology issue because of the key role $\mathrm{NO}_{\mathrm{x}}$ play in many global environmental problems, such as acid rain, photochemical smog formation, and the greenhouse effect. There is considerable political pressure for the adoption of increasingly stringent emission standards. Among the emerging technologies for $\mathrm{NO}_{\mathrm{x}}$ decomposition, non-thermal plasma is one of the most promising. A pulsed corona discharge reactor (PCDR) is one of the non-thermal plasma technologies characterized by low gas temperature and high electron temperature achieved by producing high energy electrons in the gas while leaving the bulk temperature of the gas unchanged. A PCDR utilizes a high-voltage short-duration ( $<100 \mathrm{~ns})$ electrical discharge between non-uniform electrodes to produce streamers through the growth of electron avalanches formed by electron collision ionization events in the gas. ${ }^{1} \mathrm{~A}$ streamer is a region of highly ionized gas in which a variety of active radicals and chemical species are formed through electron collision reactions with the background gas. ${ }^{2}$ These active species, in turn, initiate bulk phase reactions that lead to $\mathrm{NO}_{\mathrm{x}}$ conversion.

$\mathrm{NO}_{\mathrm{x}}$ removal is generally a problem of NO removal because NO accounts for about 95 mol\% of $\mathrm{NO}_{\mathrm{x}}$ emitted. ${ }^{3}$ There are two main pathways for NO conversion: chemical oxidation and chemical reduction. Conversion of NO to its molecular elements $\left(\mathrm{N}_{2}\right.$ and $\left.\mathrm{O}_{2}\right)$ through chemical reduction is one of the most attractive methods, especially for mobile source applications.

NO conversion in $\mathrm{N}_{2}$ using non-thermal plasma has been extensively investigated. ${ }^{2,4-8}$ In such a system, $\mathrm{NO}$ is readily converted to benign gas $\left(\mathrm{N}_{2}\right.$ and $\left.\mathrm{O}_{2}\right)$ through a reduction mechanism involving $\mathrm{N}$ radicals, with formation of only small amounts of byproduct $\mathrm{N}_{2} \mathrm{O}$ (1-2\% of initial NO concentration). ${ }^{9}$ However, real combustion flue gas, for example, from furnaces 
and fired heaters, contains $1-6 \%$ of oxygen depending on combustion conditions. ${ }^{10}$ Our recent measurements indicate the oxygen concentration in diesel engine exhaust is even higher (12 14\%), which makes NO conversion more complex.

Oxygen can reduce the rate of $\mathrm{NO}$ reduction to $\mathrm{N}_{2}$ and $\mathrm{O}_{2}$ in two ways. First, as an electronegative gas (with an electron affinity of $0.45 \mathrm{eV}$ for $\mathrm{O}_{2}$ compared to about $-1.5 \mathrm{eV}$ for $\left.\mathrm{N}_{2}\right),{ }^{11,12}$ oxygen decreases the discharge current due to the electron attachment process, as found by Kanazawa et al. ${ }^{13}$ and Mok et al. ${ }^{14}$ Sathiamoorthy et al. ${ }^{2}$ investigated the $\mathrm{NO}_{\mathrm{x}}$ reaction mechanism in nitrogen and dry air by both experiment and simulation. They found that the electron density in dry air decreases by several orders of magnitude compared to that in $\mathrm{N}_{2}$ due to the effect of the electron attachment to $\mathrm{O}_{2}$. A similar effect of oxygen on the electrical discharge was observed by Gallimberti. ${ }^{15}$ Therefore, the presence of oxygen decreases the formation rate of $\mathrm{N}$ radicals, which decreases the $\mathrm{NO}$ reduction rate to benign $\mathrm{N}_{2}$ and $\mathrm{O}_{2}$. Second, oxygen has a lower dissociation energy (5.2 eV/molecule) than nitrogen (9.8 $\mathrm{eV} /$ molecule ${ }^{16}$ ), which causes electrons to preferentially interact with $\mathrm{O}_{2}$ to produce strongly oxidizing species such as $\mathrm{O}$ and $\mathrm{O}_{3}$. These oxidizing species promote the oxidation of $\mathrm{NO}$ to produce byproducts, such as $\mathrm{NO}_{2}$ and $\mathrm{N}_{2} \mathrm{O}$, instead of the desired reduction products, $\mathrm{N}_{2}$ and $\mathrm{O}_{2}$. McLarnon and Penetrante ${ }^{17}$ investigated the effect of $0-6 \%$ oxygen concentrations on $\mathrm{NO}_{\mathrm{x}}$ conversion and found that the amount of NO chemically reduced to $\mathrm{N}_{2}$ decreases and the amount of $\mathrm{NO}$ oxidized to $\mathrm{NO}_{2}$ increases, as the $\mathrm{O}_{2}$ content increases. Tas et al. ${ }^{18}$ carried out detailed studies on the effect of $\mathrm{O}_{2}$ on energy consumption and $\mathrm{NO}$ removal efficiency in $\mathrm{N}_{2}$. They found that over $90 \%$ of $\mathrm{NO}$ conversion occurs through oxidation in the presence of $\mathrm{O}_{2}$. Therefore, total $\mathrm{NO}_{\mathrm{x}}\left(\mathrm{NO}, \mathrm{NO}_{2}\right.$ and $\left.\mathrm{N}_{2} \mathrm{O}\right)$ conversion in the corona discharge remarkably declines in oxygen-rich gases, such as $\mathrm{N}_{2} / \mathrm{O}_{2} / \mathrm{NO}$ gas mixtures., 8, 19, 20 As a result of the relative ease of dissociating $\mathrm{O}_{2}$, 
under certain conditions, $\mathrm{NO}_{\mathrm{x}}$ conversion becomes negative in the presence of $\mathrm{O}_{2}$ (i.e., $\mathrm{NO}_{\mathrm{x}}$ is produced). Yan et al. ${ }^{8}$ found that the rate of oxidation reactions exceeds the rate of reduction reactions, such as $\mathrm{N}+\mathrm{NO} \rightarrow \mathrm{N}_{2}+\mathrm{O}$, when the $\mathrm{O}_{2}$ concentration is higher than $3.6 \%$. Penetrante et $a .^{21}$ found that the reduction of $\mathrm{NO}$ with ground state $\mathrm{N}$ atoms is almost completely counterbalanced by the production of $\mathrm{NO}$ at $10 \% \mathrm{O}_{2}$ concentration. Finally, Aritoshi et al. ${ }^{20}$ found that the production of $\mathrm{NO}_{\mathrm{x}}$ becomes dominant when the concentration of $\mathrm{O}_{2}$ reaches $2 \%$. These literature results show that there is a critical oxygen concentration above which the $\mathrm{NO}_{\mathrm{x}}$ formation rate exceeds the $\mathrm{NO}_{\mathrm{x}}$ decomposition rate.

However, some issues are still unclear. The first is the mechanism of NO formation during electrical discharge in the presence of $\mathrm{O}_{2}$. Gentile and Kushner ${ }^{22,}{ }^{23}$ investigated microstreamer dynamics during plasma remediation of NO using atmospheric pressure dielectric barrier discharges. They reported that NO formation occurs through reaction with ground state $\mathrm{N}$ radicals, $\mathrm{N}\left({ }^{4} \mathrm{~S}\right)$, by the reaction $\mathrm{N}\left({ }^{4} \mathrm{~S}\right)+\mathrm{O}_{2} \rightarrow \mathrm{NO}+\mathrm{O}$ because local energy deposition in the streamers can produce high temperatures that initiate advection and facilitate production of NO. Kim et al., ${ }^{24}$ Lowke and Morrow ${ }^{25}$ and Mukkavilli et al. ${ }^{26}$ proposed a similar mechanism of NO formation. However, Aritoshi et al. ${ }^{20}$ proposed that excited $\mathrm{N}$ radicals, $\mathrm{N}\left({ }^{2} \mathrm{D}\right)$, are the primary species responsible for $\mathrm{NO}$ formation, through the reaction $\mathrm{N}\left({ }^{2} \mathrm{D}\right)+\mathrm{O}_{2} \rightarrow \mathrm{NO}+\mathrm{O}$. Herron, ${ }^{7}$ Yan

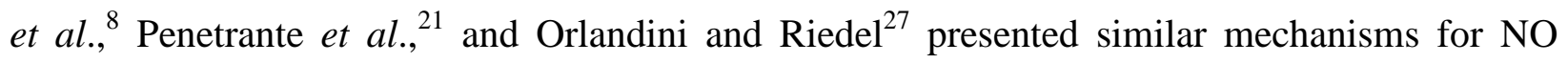
formation. Second, the formation and conversion of byproducts are rarely reported and explained, especially for $\mathrm{N}_{2} \mathrm{O}$. Third, the relationship between the rate of electron collision reactions and oxygen content and the selectivity of electron collision reactions for the dissociation of $\mathrm{N}_{2}$ and $\mathrm{O}_{2}$ are rarely reported. Finally, the critical oxygen content may change 
with the initial NO concentration, but no detailed studies on the critical oxygen content have been reported.

Therefore, the goals of this work are to study the effect of $\mathrm{O}_{2}$ on $\mathrm{NO}$ conversion in a PCDR, through experiments and simulation, to clarify the mechanism of $\mathrm{NO}_{\mathrm{x}}$ formation and conversion in the presence of $\mathrm{O}_{2}$, to understand the relationship between the rate of electron collision reactions and oxygen content, and to study the relationship between the critical oxygen content and initial NO concentration.

\section{Experimental}

The experimental setup is shown in Figure 1. The test gas was prepared by mixing the gas from the two sets of gas cylinders, one set with $\mathrm{NO}$ in $\mathrm{N}_{2}$ (three concentrations were used: 655 ppm NO, 659 ppm NO, or 800 ppm NO in ultra high purity $\mathrm{N}_{2}$, US Airgas) and the other set with $\mathrm{O}_{2}$ in $\mathrm{N}_{2}$ (four concentrations were used, approximately: 5\% $\mathrm{O}_{2}, 10 \% \mathrm{O}_{2}, 15 \% \mathrm{O}_{2}$ and $30 \%$ $\mathrm{O}_{2}$ in ultra high purity $\mathrm{N}_{2}$, USAirgas). These gases were mixed through a careful flow rate control to obtain the desired concentrations of $\mathrm{NO}$ and $\mathrm{O}_{2}$ in nitrogen fed to PCDR shown in Table 1. The PCDR feed was prepared and maintained at ambient temperature ( $300 \mathrm{~K})$. The pressure in the PCDR was maintained at $217 \mathrm{kPa}$ with control valves on the outlet gas lines. The oxygen concentration at the PCDR outlet was analyzed using a Hewlett Packard 5890 series II Gas Chromatograph (GC) with a thermal conductivity detector (TCD) and an Alltech CTR I column (outer tube with $6 \mathrm{ft} \times 1 / 4^{\prime \prime}$ packing of activated molecular sieve and inner tube with $6 \mathrm{ft}$ $\times 1 / 8^{\prime \prime}$ packing of porous polymer mixture). The outlet gas was collected in $300 \mathrm{ml}$ stainless steel cylinders (as shown in Figure 1) and analyzed for stable nitrogen oxides using a Spectrum 2000 Perkin-Elmer Fourier transform infrared spectrometer (FTIR) with a narrow-band mercury cadmium telluride (MCT) detector. 
The PCDR used in this work consisted of a high-voltage power supply with control unit and pulser/reactor assembly, as explained previously in detail. ${ }^{28}$ The high voltage controller contained electronic and gas controls required to regulate the high voltage charging power supply as well as the pulsed power delivered to the reactor gas. The pulser/reactor assembly contained the pulsed power generator and the pulsed corona discharge reaction chambers. The reactor had ten parallel reaction tubes, each $914 \mathrm{~mm}$ in length and $23 \mathrm{~mm}$ in diameter, with a stainless steel wire, $0.58 \mathrm{~mm}$ in diameter, passing axially through the center of each tube. The wire was positively charged and the tube was grounded. The gas flowing through the reactor tube was converted to a plasma by high voltage discharge from the reactor anodes. One tube was fitted with UV-grade quartz windows for diagnostics and plasma observation. The energy delivered to the reactor per pulse can be calculated either from time integral of the product of the measured pulse discharge voltage $(V)$ and current (I) or from $(1 / 2) \mathrm{CV}_{\mathrm{c}}{ }^{2}$, where $\mathrm{C}$ is the pulse forming capacitance, $800 \mathrm{pF}$; $\mathrm{V}_{\mathrm{c}}$ is the constant charge voltage, $19.2 \pm 1 \mathrm{kV}$, in the pulse forming capacitance before discharge. The discrepancy between the calculated values for energy per pulse using these two methods is measured to be less than $3 \%$. Since the current can fluctuate and be shifted in phase relative to voltage, and since the delay times of the voltage sensor and current sensor cannot be measured accurately, the second method should be more reliable. Therefore, the second method, $(1 / 2) \mathrm{CV}_{\mathrm{c}}{ }^{2}$, is used to calculate energy input per pulse in this work. The power consumed, $\mathrm{W}\left(\mathrm{J} \cdot \mathrm{s}^{-1}\right)$, is calculated as the product of the input energy per pulse and the pulse frequency. The specific energy input, Es $\left(\mathrm{kJ} \cdot \mathrm{m}^{-3}\right)$, is defined as

$$
E s=\frac{W}{1000 \cdot u}
$$

where $\mathrm{u}$ is gas flowrate $\left(\mathrm{m}^{3} \cdot \mathrm{s}^{-1}\right)$. The system design permitted variation and measurement of the applied voltage and frequency and of the reactor current and voltage. 
The plasma reactor described above was modeled using a lumped kinetic model that describes the evolution of all species, reported elsewhere. ${ }^{5}$

\section{Results and Discussion}

\section{Experimental observations}

Figure 2 shows the FTIR spectra for $\mathrm{NO}$ conversion in $\mathrm{N}_{2}$ (Figure 2(a)) and in $4.60 \% \mathrm{O}_{2}$ in $\mathrm{N}_{2}$ (Figure 2(b)) at a pulse frequency of $200 \mathrm{~Hz}$ and applied voltage of $\sim 20 \mathrm{kV}$. Similar FTIR spectra were obtained during NO conversion with the other oxygen concentrations shown in Table 1. Only NO, $\mathrm{NO}_{2}$ and $\mathrm{N}_{2} \mathrm{O}$ were detected in these spectra of the outlet gas from the PCDR. Other nitrogen oxides, such as $\mathrm{N}_{2} \mathrm{O}_{5}$ (peaks expected at 787.90-793.89 $\mathrm{cm}^{-1}$ and 1217.09$1305.73 \mathrm{~cm}^{-1}$ ), ${ }^{29}$ and $\mathrm{O}_{3}$ (peaks expected at $\left.980-1080 \mathrm{~cm}^{-1}\right)^{29}$ were not detected. The FTIR detection limit is 5 ppm for both nitrogen oxides and ozone. Herron ${ }^{7}$ simulated the NO reaction in dry air and found that $\mathrm{N}_{2} \mathrm{O}_{5}$ should be formed as a terminal product, but no experimental data support this conclusion.

Figures 3(a), (b) and (c) show the evolution of $\mathrm{NO}, \mathrm{NO}_{2}$ and $\mathrm{N}_{2} \mathrm{O}$ concentrations, respectively, as functions of specific energy inputs. In the absence of $\mathrm{O}_{2}$, the NO concentration decreases quickly to zero with increasing specific energy input (filled squares in Figure 3(a)). The $\mathrm{NO}_{2}$ concentration initially increases to a maximum with increasing specific energy input, and then decreases to zero at the same specific energy input at which the NO concentration reaches zero (filled squares in Figure 3(b)). The $\mathrm{N}_{2} \mathrm{O}$ concentration also increases to a maximum and then decreases to a constant value with increasing specific energy input (filled squares in Figure 3(c)). Figure 3(d) shows the $\mathrm{NO}_{\mathrm{x}}$ conversion as a function of specific energy input. The $\mathrm{NO}_{\mathrm{x}}$ conversion can be defined as the fraction of $\mathrm{NO}$ converted to $\mathrm{N}_{2}$, expressed as follows: 


$$
X_{\mathrm{NO}_{x}}=\frac{C_{i, \mathrm{NO}}-C_{o, \mathrm{NO}}-C_{o, \mathrm{NO}_{2}}-2 \times C_{o, \mathrm{~N}_{2} \mathrm{O}}}{C_{i, \mathrm{NO}}} \times 100 \%
$$

where $C_{i}$ is the concentration of a given species at the reactor inlet (ppm) and $C_{o}$ is the concentration of a given species at the reactor outlet (ppm). In the absence of $\mathrm{O}_{2}$, the overall $\mathrm{NO}_{\mathrm{x}}$ conversion initially increases linearly with increasing specific energy input until reaching a constant value at $98.5 \pm 0.5 \%$ because of the difficulty of converting $\mathrm{N}_{2} \mathrm{O}$ (filled squares). ${ }^{4,5,9}$ This behavior of $\mathrm{NO}_{\mathrm{x}}$ concentrations in pure $\mathrm{N}_{2}$ can be explained quantitatively using the reaction mechanism developed previously. ${ }^{4,5,9}$

However, when oxygen is present, the NO conversion and byproduct formation is more complex. At low $\mathrm{O}_{2}$ concentrations, for example 2.28\% $\mathrm{O}_{2}$ (open circles in Figure 3(a)), the NO concentration decreases quickly with increasing specific energy input for low specific energies $\left(<100 \mathrm{~kJ} / \mathrm{m}^{3}\right)$, but at high specific energy input $\left(>100 \mathrm{~kJ} / \mathrm{m}^{3}\right)$, it decreases slowly with increasing specific energy input. NO is not fully converted at the highest specific energy tested. At high $\mathrm{O}_{2}$ concentrations $\left(\geq 4.60 \% \mathrm{O}_{2}\right.$, open triangles in Figure $3(\mathrm{a})$ ), the NO concentration initially decreases with increasing specific energy input until it reaches a minimum, after which it increases slowly with increasing specific energy input. Figure 3(b) shows that the $\mathrm{NO}_{2}$ concentration forms a shallow maximum at the two lower oxygen concentrations, while it increases continually with increasing specific energy at the two higher oxygen concentrations. $\mathrm{NO}_{2}$ cannot be completely converted in the presence of $\mathrm{O}_{2}$ at the same specific energy inputs at which $\mathrm{NO}_{2}$ is completely converted in the absence of $\mathrm{O}_{2}$. In contrast to $\mathrm{N}_{2} \mathrm{O}$ in the absence of oxygen, Figure 3(c) shows that there is no maximum for $\mathrm{N}_{2} \mathrm{O}$ formation in the presence of oxygen. The $\mathrm{N}_{2} \mathrm{O}$ concentration increases continuously with increasing specific energy input. At a given specific energy input, the amount of $\mathrm{NO}_{2}$ and $\mathrm{N}_{2} \mathrm{O}$ formed increases with increasing oxygen content, as shown in Figures 3(b) and (c), respectively. The $\mathrm{NO}_{\mathrm{x}}$ conversion shown in 
Figure 3(d) changes from a positive value to a negative value for all oxygen concentrations greater than $\sim 2.5 \%$. According to Eq. (2), a positive $\mathrm{NO}_{\mathrm{x}}$ conversion means that some $\mathrm{NO}$ is converted to $\mathrm{N}_{2}$ and $\mathrm{O}_{2}$. However, a negative $\mathrm{NO}_{\mathrm{x}}$ conversion means that the amount of $\mathrm{NO}_{\mathrm{x}}$ formed is greater than the amount of $\mathrm{NO}$ reduced to $\mathrm{N}_{2} / \mathrm{O}_{2}$. The amount of $\mathrm{NO}_{\mathrm{x}}$ formed increases with increasing oxygen concentration. This phenomenon will be further discussed in terms of the lumped model. ${ }^{5}$

\section{Electron Collision Reactions}

The collisions of energetic electrons produced by the electrical discharge with gas molecules produce chemically active species, such as radicals and ions, which contribute to $\mathrm{NO}_{\mathrm{x}}$ formation and conversion. ${ }^{30}$ The initial selectivity analysis developed recently ${ }^{4}$ was used to identify the chemically active species produced by electron collision reactions that are important in $\mathrm{NO}_{\mathrm{x}}$ formation and conversion. For this analysis, electron interactions with species other than $\mathrm{N}_{2}$ and $\mathrm{O}_{2}$ were not considered since their concentrations relative to $\mathrm{N}_{2}$ and $\mathrm{O}_{2}$ are always very low. ${ }^{50}$ Further, McLarnon and Penetrante ${ }^{17}$ found that charged species do not contribute significantly to $\mathrm{NO}_{\mathrm{x}}$ conversion. Our previous investigation ${ }^{4}$ on $\mathrm{NO}_{\mathrm{x}}$ conversion in non-thermal nitrogen plasma confirmed that cations, such as $\mathrm{N}_{2}{ }^{+}$, do not contribute to $\mathrm{NO}_{\mathrm{x}}$ conversion. Therefore, reactions with ions are not considered in this analysis.

As reported recently, ${ }^{4}$ the possible chemically active species formed from electron collision reactions with nitrogen include $\mathrm{N}_{2}\left(\mathrm{~A}^{3} \sum_{\mathrm{u}}{ }^{+}\right), \mathrm{N}_{2}\left(\mathrm{~B}^{3} \prod_{\mathrm{g}}\right), \mathrm{N}_{2}\left(\mathrm{~B}^{\prime 3} \sum_{\mathrm{u}}{ }^{-}\right), \mathrm{N}_{2}\left(\mathrm{a}^{\prime}{ }^{1} \sum_{\mathrm{u}}{ }^{-}\right), \mathrm{N}_{2}\left(\mathrm{a}^{1} \prod_{\mathrm{g}}\right)$, $\mathrm{N}_{2}\left(\mathrm{~W}^{1} \Delta_{\mathrm{u}}\right), \mathrm{N}_{2}\left(\mathrm{C}^{3} \prod_{\mathrm{u}}\right), \mathrm{N}_{2}\left(\mathrm{E}^{3} \Sigma_{\mathrm{g}}^{+}\right), \mathrm{N}\left({ }^{4} \mathrm{~S}\right)$, and $\mathrm{N}\left({ }^{2} \mathrm{D}\right)$. An initial selectivity analysis of systematic experiments performed in absence of $\mathrm{O}_{2}$ showed that the active species which play an important role in $\mathrm{NO}_{\mathrm{x}}$ conversion are $\mathrm{N}_{2}\left(\mathrm{~A}^{3} \sum_{\mathrm{u}}{ }^{+}\right)$and $\mathrm{N}\left({ }^{4} \mathrm{~S}\right) .{ }^{4}$ Other active species are mainly quenched to the ground state by the nitrogen background gas. However, at percent-level $\mathrm{O}_{2}$ concentrations, 
the situation may be different because these active species contribute to $\mathrm{O}_{2}$ dissociation or $\mathrm{NO}_{\mathrm{x}}$ formation by the following reactions (at $300 \mathrm{~K}$ ):

$$
\begin{array}{ll}
\mathrm{N}_{2}\left(\mathrm{~A}^{3} \sum_{\mathrm{u}}^{+}\right)+\mathrm{O}_{2} \rightarrow \mathrm{N}_{2}+\mathrm{O}+\mathrm{O} & \mathrm{k}=1.51 \times 10^{12} \mathrm{~cm}^{3} \cdot \mathrm{mol}^{-1} \cdot \mathrm{s}^{-1} \\
\mathrm{~N}_{2}\left(\mathrm{~B}^{3} \prod_{\mathrm{g}}\right)+\mathrm{O}_{2} \rightarrow \mathrm{N}_{2}+\mathrm{O}+\mathrm{O} & \mathrm{k}=1.20 \times 10^{14} \mathrm{~cm}^{3} \cdot \mathrm{mol}^{-1} \cdot \mathrm{s}^{-1} \\
\mathrm{~N}_{2}\left(\mathrm{C}^{3} \prod_{\mathrm{u}}\right)+\mathrm{O}_{2} \rightarrow \mathrm{N}_{2}+\mathrm{O}+\mathrm{O} & \mathrm{k}=1.81 \times 10^{14} \mathrm{~cm}^{3} \cdot \mathrm{mol}^{-1} \cdot \mathrm{s}^{-1} \\
\mathrm{~N}_{2}\left(\mathrm{a}^{1} \sum_{\mathrm{u}}{ }^{-}\right)+\mathrm{O}_{2} \rightarrow \mathrm{N}_{2}+\mathrm{O}+\mathrm{O} & \mathrm{k}=1.69 \times 10^{13} \mathrm{~cm}^{3} \cdot \mathrm{mol}^{-1} \cdot \mathrm{s}^{-1} \\
\mathrm{~N}_{2}\left(\mathrm{a}^{1} \prod_{\mathrm{g}}\right)+\mathrm{O}_{2} \rightarrow \mathrm{N}_{2}+\mathrm{O}+\mathrm{O} & \mathrm{k}=2.59 \times 10^{14} \mathrm{~cm}^{3} \cdot \mathrm{mol}^{-1} \cdot \mathrm{s}^{-1} \\
\mathrm{~N}\left({ }^{2} \mathrm{D}\right)+\mathrm{O}_{2} \rightarrow \mathrm{NO}+\mathrm{O} & \mathrm{k}=3.13 \times 10^{12} \mathrm{~cm}^{3} \cdot \mathrm{mol}^{-1} \cdot \mathrm{s}^{-1} \\
\mathrm{~N}\left({ }^{4} \mathrm{~S}\right)+\mathrm{O}_{2} \rightarrow \mathrm{NO}+\mathrm{O} & \mathrm{k}=5.91 \times 10^{7} \mathrm{~cm}^{3} \cdot \mathrm{mol}^{-1} \cdot \mathrm{s}^{-1}
\end{array}
$$

Therefore, the chemically active species produced by electron collision reactions with nitrogen may be consumed by four parallel processes:

(1) Natural radiation accompanying optical emission:

$$
\mathrm{A}^{*} \rightarrow \mathrm{A}+\mathrm{h} v \quad \mathrm{R}_{\mathrm{I}}=\mathrm{k}_{\mathrm{I}} \cdot \mathrm{C}_{\mathrm{A}^{*}}
$$

(2) Quenching with the background gas $\mathrm{N}_{2}$ :

$$
\mathrm{A}^{*}+\mathrm{N}_{2} \rightarrow \mathrm{A}+\mathrm{N}_{2} \quad \mathrm{R}_{\mathrm{q}}=\mathrm{k}_{\mathrm{q}} \cdot \mathrm{C}_{\mathrm{A}} \cdot \mathrm{C}_{\mathrm{N} 2}
$$

(3) Dissociative quenching or reaction with background gas $\mathrm{O}_{2}$ :

$$
\mathrm{A}^{*}+\mathrm{O}_{2} \rightarrow \text { products } \quad \mathrm{R}_{\mathrm{d}}=\mathrm{k}_{\mathrm{d}} \cdot \mathrm{C}_{\mathrm{A}^{*}} \cdot \mathrm{C}_{\mathrm{O} 2}
$$

(4) Reaction with $\mathrm{NO}_{\mathrm{x}}$ (conversion of $\mathrm{NO}_{\mathrm{x}}$ ):

$$
\mathrm{A}^{*}+\mathrm{NO}_{\mathrm{x}} \rightarrow \text { products } \quad \mathrm{R}_{\mathrm{r}}=\mathrm{k}_{\mathrm{r}} \cdot \mathrm{C}_{\mathrm{A}^{*}} \cdot \mathrm{C}_{\mathrm{NOx}}
$$

In these chemical equations, $A *$ represents any active species; $k_{\mathrm{l}}, \mathrm{k}_{\mathrm{q}}, \mathrm{k}_{\mathrm{d}}$ and $\mathrm{k}_{\mathrm{r}}$ are the rate constants of radiation, quenching, dissociative quenching of $\mathrm{O}_{2}$, and $\mathrm{NO}_{\mathrm{x}}$ conversion, respectively; and $R_{i}$ is the reaction rate of reaction type $i$. The initial selectivity of these four parallel processes can be defined as 


$$
\begin{aligned}
& S_{I}=\frac{R_{I}}{R_{I}+R_{q}+R_{d}+R_{r}}=\frac{k_{I}}{k_{I}+k_{q} C_{N_{2}}+k_{d} C_{O_{2}}+k_{r} C_{N O x}} \times 100 \% \\
& S_{q}=\frac{R_{q}}{R_{I}+R_{q}+R_{d}+R_{r}}=\frac{k_{q} C_{N_{2}}}{k_{I}+k_{q} C_{N_{2}}+k_{d} C_{O_{2}}+k_{r} C_{N O x}} \times 100 \% \\
& S_{d}=\frac{R_{d}}{R_{I}+R_{q}+R_{d}+R_{r}}=\frac{k_{d} C_{O_{2}}}{k_{I}+k_{q} C_{N_{2}}+k_{d} C_{O_{2}}+k_{r} C_{N O x}} \times 100 \% \\
& S_{r}=\frac{R_{r}}{R_{I}+R_{q}+R_{d}+R_{r}}=\frac{k_{r} C_{N^{O X}}}{k_{I}+k_{q} C_{N_{2}}+k_{d} C_{O_{2}}+k_{r} C_{N O X}} \times 100 \%
\end{aligned}
$$

where $S_{\mathrm{I}}, S_{\mathrm{q}}, \mathrm{S}_{\mathrm{d}}$ and $\mathrm{S}_{\mathrm{r}}$ are the initial selectivities to radiative emission reactions, quenching reactions, $\mathrm{O}_{2}$ dissociation, and $\mathrm{NO}_{\mathrm{x}}$ conversion reactions, respectively.

The analysis of initial selectivity is an effective method to examine the significance of the active species. Only the active species which contribute predominantly to $\mathrm{NO}_{\mathrm{x}}$ formation and conversion need to be considered. In this work, the highest $\mathrm{NO}_{\mathrm{x}}$ concentration in the presence of $\mathrm{O}_{2}$ is less than $600 \mathrm{ppm}$, while the lowest $\mathrm{O}_{2}$ concentration is $2.28 \%(\mathrm{~mol} / \mathrm{mol})$ in the $\mathrm{N}_{2}$ balance gas. At $217 \mathrm{kPa}$ and $300 \mathrm{~K}$, these concentrations of $\mathrm{NO}_{\mathrm{x}}, \mathrm{O}_{2}$ and $\mathrm{N}_{2}$ are $5.21 \times 10^{-8} \mathrm{~mol} / \mathrm{cm}^{3}$, $1.98 \times 10^{-6} \mathrm{~mol} / \mathrm{cm}^{3}$, and $8.49 \times 10^{-5} \mathrm{~mol} / \mathrm{cm}^{3}$, respectively. Substituting these concentrations and the rate constants for consumption of active species $\left(\mathrm{A}^{*}\right)$ by radiation, quenching, dissociative quenching of $\mathrm{O}_{2}$, and $\mathrm{NO}_{\mathrm{x}}$ conversion (summarized in our previous work ${ }^{4}$ ) in equations 3a through 3d, yields the initial selectivities for the four parallel processes presented in Table 2. These results indicate that all of the electronic excited states of molecular nitrogen contribute predominantly to $\mathrm{O}_{2}$ dissociation or quenching. Moreover, with increasing $\mathrm{O}_{2}$ concentration, the contribution of these active species to $\mathrm{O}_{2}$ dissociation further increases.

Therefore, only $\mathrm{N}\left({ }^{2} \mathrm{D}\right)$, which is an excited atomic $\mathrm{N}$ radical, and $\mathrm{N}\left({ }^{4} \mathrm{~S}\right)$, which is the ground state atomic $\mathrm{N}$ radical, may directly contribute to NO formation through reactions R6 and 
R7. However, a simple comparison shows that $N\left({ }^{4} S\right)$ cannot contribute significantly to NO formation regardless of the $\mathrm{N}\left({ }^{4} \mathrm{~S}\right)$ concentration. Under the most conservative circumstance of low NO concentration (e.g. $50 \mathrm{ppm} \mathrm{NO}$ in the presence of $\mathrm{O}_{2}$ in the reactor, shown in Figure 3(a)), the rate of $\mathrm{NO}$ formation by R7 is about 500 times lower than the rate of NO decomposition by reaction $\mathrm{N}\left({ }^{4} \mathrm{~S}\right)+\mathrm{NO} \rightarrow \mathrm{N}_{2}+\mathrm{O}$, which has a rate constant of $1.87 \times 10^{13}$ $\mathrm{cm}^{3} \cdot \mathrm{mol}^{-1} \cdot \mathrm{s}^{-1} \cdot{ }^{38}$ Therefore, $\mathrm{N}\left({ }^{4} \mathrm{~S}\right)$ atoms are mainly consumed in reactions with $\mathrm{NO}$ and $\mathrm{NO}_{2}$. As a result, the mechanism of $\mathrm{NO}$ formation is predominantly through $\mathrm{N}\left({ }^{2} \mathrm{D}\right)$ in R6. With increasing oxygen concentration, the selectivity of NO formation through $N\left({ }^{2} D\right)$ further increases. Cosby ${ }^{39}$ found that the dominant dissociation mechanism in pure $\mathrm{N}_{2}$ plasmas is $\mathrm{N}_{2} \rightarrow \mathrm{N}\left({ }^{2} \mathrm{D}\right)+\mathrm{N}\left({ }^{4} \mathrm{~S}\right)$, indicating that approximately equal amounts of $\mathrm{N}\left({ }^{2} \mathrm{D}\right)$ and $\mathrm{N}\left({ }^{4} \mathrm{~S}\right)$ are formed. Hill et al. ${ }^{40}$ found that the yield of $\mathrm{N}\left({ }^{2} \mathrm{D}\right)$ during $\mathrm{N}_{2}$ dissociation in air corona discharges is $\sim 67 \%$, which means that $N\left({ }^{2} D\right)$ is formed at twice the rate of $N\left({ }^{4} S\right)$. Both of these results are consistent with the proposal that $\mathrm{NO}$ formation occurs through reaction with $\mathrm{N}\left({ }^{2} \mathrm{D}\right)$ in R6, but they do not provide a consistent value for the relative proportions of $\mathrm{N}\left({ }^{2} \mathrm{D}\right)$ and $\mathrm{N}\left({ }^{4} \mathrm{~S}\right)$.

Similar to electron collisions with nitrogen, many active species may be produced when electrons collide with molecular oxygen. Again, the active oxygen species that actually contribute to $\mathrm{NO}_{\mathrm{x}}$ formation and conversion must be determined. The potential energy curve of molecular and atomic oxygen is reported in reference 41. Only two electronic states of $\mathrm{O}$ atoms $\left[\mathrm{O}\left({ }^{3} \mathrm{P}\right)\right.$ and $\left.\mathrm{O}\left({ }^{1} \mathrm{D}\right)\right]$ are energetically accessible at the experimental conditions of this study because the average electron energy in the PCDR is less than $10 \mathrm{eV},{ }^{42,43}$ as supported by investigation of Eliasson and Kogelschatz. ${ }^{44} \mathrm{O}\left({ }^{3} \mathrm{P}\right)$ and $\mathrm{O}\left({ }^{1} \mathrm{D}\right)$ are the ground state and the first electronic excited state of atomic O radicals, respectively. Therefore, the possible chemically active species formed from electron collision reactions with oxygen are $\mathrm{O}_{2}\left(\mathrm{a}^{1} \Delta_{\mathrm{g}}\right), \mathrm{O}_{2}\left(\mathrm{~b}^{1} \sum_{\mathrm{g}}{ }^{+}\right)$, 
$\mathrm{O}_{2}\left(\mathrm{c}^{1} \sum_{\mathrm{u}}^{-}\right), \quad \mathrm{O}_{2}\left(\mathrm{C}^{3} \Delta_{\mathrm{u}}\right), \quad \mathrm{O}_{2}\left(\mathrm{~A}^{3} \Sigma_{\mathrm{u}}^{+}\right), \quad \mathrm{O}_{2}\left({ }^{3} \Pi_{\mathrm{u}}\right), \quad \mathrm{O}_{2}\left(\left(^{1} \Pi_{\mathrm{u}}\right), \quad \mathrm{O}_{2}\left({ }^{3} \sum_{\mathrm{g}}^{-}\right), \quad \mathrm{O}_{2}\left(\mathrm{~B}^{3} \sum_{\mathrm{u}}{ }^{-}\right), \quad \mathrm{O}_{2}\left({ }^{1} \prod_{\mathrm{g}}\right), \quad \mathrm{O}_{2}\left({ }^{1} \Delta_{\mathrm{u}}\right)\right.$, $\mathrm{O}_{2}\left({ }^{1} \Delta_{\mathrm{g}}\right), \mathrm{O}\left({ }^{3} \mathrm{P}\right)$, and $\mathrm{O}\left({ }^{1} \mathrm{D}\right)$, which can be consumed by natural radiation, reaction, quenching with $\mathrm{N}_{2}, \mathrm{O}_{2}$, or $\mathrm{NO}_{\mathrm{x}}$.

Table 3 lists these possible interactions. Extensive literature reviews ${ }^{45,}{ }^{46}$ reported no reactions with or quenching by the following molecular $\mathrm{O}_{2}$ electronic excited states: $\mathrm{O}_{2}\left(\prod_{u}\right)$, $\mathrm{O}_{2}\left({ }^{1} \prod_{\mathrm{u}}\right), \mathrm{O}_{2}\left({ }^{3} \Sigma_{\mathrm{g}}\right), \mathrm{O}_{2}\left({ }^{1} \prod_{\mathrm{g}}\right), \mathrm{O}_{2}\left({ }^{1} \Delta_{\mathrm{u}}\right)$ and $\mathrm{O}_{2}\left({ }^{1} \Delta_{\mathrm{g}}\right)$. The data in Table 3 show that $\mathrm{O}_{2}\left(\mathrm{a}^{1} \Delta_{\mathrm{g}}\right)$, $\mathrm{O}_{2}\left(\mathrm{~b}^{1} \sum_{\mathrm{g}}^{+}\right), \mathrm{O}_{2}\left(\mathrm{c}^{1} \sum_{\mathrm{u}}^{-}\right), \mathrm{O}_{2}\left(\mathrm{C}^{3} \Delta_{\mathrm{u}}\right)$ and $\mathrm{O}_{2}\left(\mathrm{~A}^{3} \sum_{\mathrm{u}}^{+}\right)$are mainly quenched to the ground state, while $\mathrm{O}_{2}\left(\mathrm{~B}^{3} \sum_{\mathrm{u}}^{-}\right)$mainly returns to the ground state through radiative emission because of the short radiative lifetime of about $40 \mathrm{~ns}^{47}$ Therefore, the excited states of molecular oxygen are essentially unreactive, which supports the conjecture of Herron. ${ }^{7}$

As a result, only $\mathrm{O}\left({ }^{1} \mathrm{D}\right)$ or $\mathrm{O}\left({ }^{3} \mathrm{P}\right)$ or both are involved in the $\mathrm{NO}_{\mathrm{x}}$ formation mechanism. The rate constants for the quenching reactions of $\mathrm{O}\left({ }^{1} \mathrm{D}\right)$ by $\mathrm{N}_{2}$ and $\mathrm{O}_{2}(\mathrm{R} 31$ and R32) are equal to or up to four times lower than the rate constants for the reactions of $\mathrm{O}\left({ }^{1} \mathrm{D}\right)$ and $\mathrm{NO}_{\mathrm{x}}(\mathrm{R} 33-\mathrm{R} 36)$, while the total concentration of $\mathrm{N}_{2}$ and $\mathrm{O}_{2}$ is 167 times higher than that of $\mathrm{NO}_{\mathrm{x}}$ (based on 600 ppm $\left.\mathrm{NO}_{\mathrm{x}}\right)$. Comparison of the reaction rates of R31-32 with those of R33-36 shows that $\mathrm{O}\left({ }^{1} \mathrm{D}\right)$ would be quenched by the background nitrogen and oxygen because the total reaction rate of R31-32 is at least 40 times higher than R33-36 at the prevailing reactant concentrations and any assumed $\mathrm{O}\left({ }^{1} \mathrm{D}\right)$ concentration. Therefore, only ground state $\mathrm{O}$ atoms, $\mathrm{O}\left({ }^{3} \mathrm{P}\right)$, contribute to $\mathrm{NO}_{\mathrm{x}}$ evolution among all of the active species produced from electron collision reactions with molecular oxygen.

\section{Mechanism and kinetics}

The previous discussion on electron collision reactions with oxygen indicates that, although many electron collision reactions with $\mathrm{O}_{2}$ occur in the PCDR, only the $\mathrm{O}_{2}$ dissociation 
reaction must be considered because only $\mathrm{O}$ atoms contribute to $\mathrm{NO}_{\mathrm{x}}$ formation. Therefore, only the following electron collision reaction is considered for molecular $\mathrm{O}_{2}$ :

$$
\mathrm{e}+\mathrm{O}_{2} \rightarrow \mathrm{O}\left({ }^{3} \mathrm{P}\right)+\mathrm{O}\left({ }^{3} \mathrm{P}\right)+\mathrm{e}
$$

As the earlier discussion on electron collision reactions with nitrogen has shown, almost all active species can contribute to $\mathrm{NO}_{\mathrm{x}}$ evolution, either directly through formation of $\mathrm{NO}_{\mathrm{x}}$ by $\mathrm{N}\left({ }^{2} \mathrm{D}\right)$ or indirectly through $\mathrm{O}_{2}$ dissociation reactions with these excited $\mathrm{N}_{2}$ species. Therefore, all electron collision reactions resulting in active species formation are considered: ${ }^{4}$

$$
\begin{aligned}
& \mathrm{e}+\mathrm{N}_{2} \rightarrow \mathrm{N}\left({ }^{4} \mathrm{~S}\right)+\mathrm{N}\left({ }^{4} \mathrm{~S}\right)+\mathrm{e} \\
& \mathrm{e}+\mathrm{N}_{2} \rightarrow \mathrm{N}\left({ }^{2} \mathrm{D}\right)+\mathrm{N}\left({ }^{2} \mathrm{D}\right)+\mathrm{e} \\
& \mathrm{e}+\mathrm{N}_{2} \rightarrow \mathrm{N}_{2}\left(\mathrm{~A}^{3} \sum_{\mathrm{u}}^{+}\right)+\mathrm{e} \\
& \mathrm{e}+\mathrm{N}_{2} \rightarrow \mathrm{N}_{2}\left(\mathrm{~B}^{3} \prod_{\mathrm{g}}\right)+\mathrm{e} \\
& \mathrm{e}+\mathrm{N}_{2} \rightarrow \mathrm{N}_{2}\left(\mathrm{~B}^{\prime 3} \sum_{\mathrm{u}}^{-}\right)+\mathrm{e} \\
& \mathrm{e}+\mathrm{N}_{2} \rightarrow \mathrm{N}_{2}\left(\mathrm{a}^{\prime} \sum_{\mathrm{u}}^{-}\right)+\mathrm{e} \\
& \mathrm{e}+\mathrm{N}_{2} \rightarrow \mathrm{N}_{2}\left(\mathrm{a}^{1} \prod_{\mathrm{g}}\right)+\mathrm{e} \\
& \mathrm{e}+\mathrm{N}_{2} \rightarrow \mathrm{N}_{2}\left(\mathrm{~W}^{1} \Delta_{\mathrm{u}}\right)+\mathrm{e} \\
& \mathrm{e}+\mathrm{N}_{2} \rightarrow \mathrm{N}_{2}\left(\mathrm{C}^{3} \prod_{\mathrm{u}}\right)+\mathrm{e} \\
& \mathrm{e}+\mathrm{N}_{2} \rightarrow \mathrm{N}_{2}\left(\mathrm{E}^{3} \sum_{\mathrm{g}}^{+}\right)+\mathrm{e}
\end{aligned}
$$

The rate constant of electron collision reactions is a function of electron energy distribution and the cross sections of electronic excitation and molecular dissociation. ${ }^{26}$ However, the electron energy distribution in the plasma is complicated and not measurable because the electric field is strongly non-uniform, due to strong space-charge field effects, and is time dependent. ${ }^{21}$ Further, there are large discrepancies in the reported values of the cross sections of electronic excitation 
and molecular dissociation. ${ }^{27}$ Therefore, a calculation for all of these rate constants of electron collision reactions with $\mathrm{N}_{2}$ is not feasible.

In our kinetic model, ${ }^{5}$ there are two parameters that describe the rate constant of each electron collision reaction, $\alpha$ and $\beta$, as shown in the following equation:

$$
k[e]=\beta \sqrt{\frac{1}{\alpha P}} W^{0.75} \exp \left(-\frac{\alpha P}{W}\right)
$$

where $\mathrm{P}$ is the system pressure and $\mathrm{W}$ is the power input. This expression, based on a Maxwellian distribution function for the electron velocity, semi-empirically describes the rate of electron collision reactions through a pseudo-first order rate constant by combining the true rate constant with the electron concentration. ${ }^{28}$ This implies that 20 model parameters would be needed to describe the ten electron collision reactions with $\mathrm{N}_{2}$ (R38-R47), too many to produce meaningful results. However, the net effect of electron collision reactions R40-R47 is the dissociation of oxygen because all electronic excited states of molecular nitrogen predominantly contribute to $\mathrm{O}_{2}$ dissociation or are selectively quenched, as shown in Table 2. Thus, a reasonable simplifying assumption is to model the net result of electron collision reactions R40R47 as the single electron collision reaction R37. The contribution of all molecular nitrogen electronic excited states to $\mathrm{O}_{2}$ dissociation is presumably far lower than that of direct electron collision reactions with $\mathrm{O}_{2}$ because the dissociation energy per oxygen molecule, $5.2 \mathrm{eV} / \mathrm{O}_{2}$, is much less than the critical electronic excitation energy of all $\mathrm{N}_{2}$ electronic excited states (Figure 1 in Reference 4).

In addition to R37, R38 and R39 (electron collision reactions that form $\mathrm{N}\left({ }^{4} \mathrm{~S}\right)$ and $\mathrm{N}\left({ }^{2} \mathrm{D}\right)$, respectively) are the only electron collision reactions assumed to be important for $\mathrm{NO}_{\mathrm{x}}$ conversion and formation in $\mathrm{N}_{2} / \mathrm{O}_{2}$ plasma. Both R38 and R39 are included due to the disagreement in previous reports on the relative amounts of $N\left({ }^{4} S\right)$ and $N\left({ }^{2} D\right)$ formed. ${ }^{39,40}$ 
Many series and parallel reactions among active species, $\mathrm{N}_{2}, \mathrm{O}_{2}$ and $\mathrm{NO}_{\mathrm{x}}$ are possible to follow the electron collision reactions. For example, Penetrante et al. ${ }^{6}$ used 287 reactions to simulate $\mathrm{NO}_{\mathrm{x}}$ evolution in a very simple system, $\mathrm{NO}$ in $\mathrm{N}_{2}$. In the present analysis, a total of 28 reactions (shown in Table 4) were selected to simulate $\mathrm{NO}_{\mathrm{x}}$ evolution based on a rough selectivity analysis to determine the controlling reactions by assuming that the slowest reaction among series reactions is the controlling step, while the fastest reaction among parallel reactions is the controlling step. These 28 reactions for $\mathrm{NO}_{\mathrm{x}}$ evolution were analyzed for the $\mathrm{NO} / \mathrm{N}_{2} / \mathrm{O}_{2}$ reaction system.

For such a system, six model parameters must be determined for the three electron collision reactions (R37-39) for the $\mathrm{NO}$ in $\mathrm{N}_{2} / \mathrm{O}_{2}$ system. There are ten components $(\mathrm{O}, \mathrm{N}$, $\left.\mathrm{N}\left({ }^{2} \mathrm{D}\right), \mathrm{NO} \mathrm{NO}_{2}, \mathrm{~N}_{2} \mathrm{O}, \mathrm{NO}_{3}, \mathrm{O}_{3}, \mathrm{O}_{2}, \mathrm{~N}_{2}\right)$ in this reaction system, as shown in Table 4. Therefore, there are ten equations for each of the eight power inputs, which leads to a total of 80 equations used to determine the six parameters $\left(\alpha_{\mathrm{i}}\right.$ and $\left.\beta_{\mathrm{i}}, \mathrm{i}=1-3\right)$ for a experimental system of $2.28 \% \mathrm{O}_{2}+$ 355 ppm NO in $\mathrm{N}_{2}$ using the previously reported optimization method. ${ }^{5}$ Figure 4 shows measured and correlated $\mathrm{NO}, \mathrm{NO}_{2}$, and $\mathrm{N}_{2} \mathrm{O}$ concentrations for the experiments listed in Table 1. The correlated curves in Figure 4 represent the experimental data, which confirms that the reaction mechanism in Table 4 is a reasonable hypothesis of $\mathrm{NO}_{\mathrm{x}}$ evolution in $\mathrm{N}_{2} / \mathrm{O}_{2}$ plasma. The concentrations of $\mathrm{N}_{2}$ and $\mathrm{O}_{2}$ at the outlet of the reactor used in the model calculations were obtained from nitrogen and oxygen material balances.

No O, $\mathrm{N}, \mathrm{O}_{3}, \mathrm{NO}_{3}$, or $\mathrm{N}_{2} \mathrm{O}_{5}$ were detected at the outlet of the reactor. The absence of the atomic radicals is consistent with their reactivity, but the absence of the other three molecules was investigated using the model. The lack of ozone in the reactor effluent (Figure 2) can be explained by reaction R65. During all experimental conditions in the presence of oxygen, the NO 
concentration is greater than $50 \mathrm{ppm}$ (Figure 3(a)). Assuming that the NO concentration is 50 $\operatorname{ppm}\left(4.34 \times 10^{-9} \mathrm{~mol} / \mathrm{cm}^{3}\right), \mathrm{O}_{3}$ conversion, calculated from the rate constant for $\mathrm{R} 65$, is shown in Figure 5 as a function of gas residence time. $\mathrm{O}_{3}$ can be completely converted in $0.1 \mathrm{~s}$ of residence time in the reactor. Therefore, $\mathrm{NO}$ and $\mathrm{O}_{3}$ do not coexist in the system. By the same reasoning, $\mathrm{NO}_{3}$ is undetectable because of reaction R66. The simulation results show that the ozone concentration is less than $1 \mathrm{ppm}$ and the $\mathrm{NO}_{3}$ concentration is less than $0.001 \mathrm{ppm}$ for all experimental conditions. $\mathrm{N}_{2} \mathrm{O}_{5}$ is not formed in detectable quantities because the low $\mathrm{NO}_{3}$ concentration limits the reaction of $\mathrm{NO}_{2}+\mathrm{NO}_{3} \rightarrow \mathrm{N}_{2} \mathrm{O}_{5}$. These model results explain why nitrogen oxides other than $\mathrm{NO}, \mathrm{NO}_{2}$ and $\mathrm{N}_{2} \mathrm{O}$ are undetectable in our experiments.

Model parameters obtained for different $\mathrm{O}_{2}$ concentrations for the three electron collision reactions (R37-R39) are shown in Figure 6. For each electron collision, model parameter $\alpha$ remains constant with oxygen concentration (Figure 6(a)). However, model parameter $\beta$ decays with oxygen concentration as a power function (Figure 6(b)-(d)). Applying a least square regression analysis to these data, $\beta$ is found to be inversely proportional to the mole fraction of oxygen to a different power for each electron collision reaction:

$$
\begin{array}{ll}
\text { For R37: } & \beta=2.00 \times 10^{-5} \cdot x_{O_{2}}^{-0.817} \\
\text { For R38: } & \beta=4.00 \times 10^{-7} \cdot x_{O_{2}}^{-0.314} \\
\text { For R39: } & \beta=5.55 \times 10^{-7} \cdot x_{O_{2}}^{-0.0726}
\end{array}
$$

where $\mathrm{x}_{\mathrm{O}_{2}}$ is the mole fraction of oxygen. All model parameters $\beta$ for electron collision reactions R37-R39 are oxygen concentration dependent because the expression for the rate constant of electron collision reactions involves the effect of electron concentration, as shown in Eq. (4). However, electron concentration changes with oxygen concentration in the plasma, as observed 
by Kanazawa et al.. ${ }^{13}$ Figure 7(a) shows the rate constants of electron collision reactions R37R39 (calculated from Eq. (4)) as a function of $\mathrm{O}_{2}$ concentration at $100 \mathrm{~W}$ power input. The rate constant of electron collision reactions decrease with increasing oxygen concentration. Oxygen is electronegative; it has a strong electron affinity $(0.45 \mathrm{eV}) .{ }^{11}$ The presence of $\mathrm{O}_{2}$ as a reactant reduces the discharge current by capturing electrons and therefore reduces the electron concentration during discharge due to the electron attachment process, as observed by Sathiamoorthy et al., ${ }^{2}$ Kanazawa et al. ${ }^{13}$ and Mok et al., ${ }^{14}$ which results in the decreasing values in the rate constants observed in Figure 7(a).

Figure 7(b) shows the ratio of the rate constant of electron collision reaction with oxygen to the rate constants of electron collision with nitrogen as a function of oxygen mole fraction at different power inputs. The rate constant for $\mathrm{N}_{2}$ dissociation is approximately two orders of magnitude less than that for $\mathrm{O}_{2}$ dissociation. McLarnon and Penetrante ${ }^{17}$ used theoretical calculations (the Boltzmann code ELENDIF) to estimate the rate constant of electron collision reactions. When they compared the ratio of the rate constants of electron collision reactions with oxygen and nitrogen, they found similar results, which support the validity of our lumped model analysis. At a constant oxygen concentration, Figure 7(b) also shows that the rate constant ratio weakly increases with increasing power input because oxygen has a lower dissociation energy compared to nitrogen dissociation, as discussed earlier.

Substituting the expressions for $\beta$ from Eq. 5(a)-(c) in Eq.(4), the expressions for the rate of electron collision reactions for R37-R39 become

$$
\begin{aligned}
& R_{37}=2.00 \times 10^{-5} \cdot x_{O_{2}}^{0.183} \cdot \sqrt{\frac{1}{\alpha P}} \cdot W^{0.75} \cdot \exp \left(-\frac{\alpha P}{W}\right) \cdot \frac{P}{R T} \\
& R_{38}=4.00 \times 10^{-7} \cdot x_{O_{2}}^{-0.314} \cdot\left(1-x_{O_{2}}\right) \cdot \sqrt{\frac{1}{\alpha P}} \cdot W^{0.75} \cdot \exp \left(-\frac{\alpha P}{W}\right) \cdot \frac{P}{R T}
\end{aligned}
$$




$$
R_{39}=5.55 \times 10^{-7} \cdot x_{O_{2}}^{-0.0726} \cdot\left(1-x_{O_{2}}\right) \cdot \sqrt{\frac{1}{\alpha P}} \cdot W^{0.75} \cdot \exp \left(-\frac{\alpha P}{W}\right) \cdot \frac{P}{R T}
$$

where $R_{n}$ is the rate of reaction $n, R$ is the gas constant, and $T$ is gas temperature. These equations indicate that the rate of the electron-oxygen collision reaction increases with increasing oxygen concentration, while the rate of electron-nitrogen collision reactions decreases with increasing oxygen content. Figure 8(a) shows these rate trends for the three electron collision reactions as a function of $\mathrm{O}_{2}$ concentration. Using the definition of selectivity given by Eq.3(a)(d), selectivities for the three parallel electron collision reactions R37-R39 are shown in Figure 8(b). The selectivity of R37 increases with increasing oxygen concentration, while the selectivity of R38 and R39 decreases with increasing oxygen concentration, which is consistent with the results in Figure 8(a). The oxygen reaction (R37) selectivity is always far higher than the selectivity of nitrogen reactions (R38 and R39) over the range of oxygen concentrations examined in this work, which is consistent with the results reported by Penetrante $e$ al. $^{21}$ They found that discharge plasma conditions with mean electron energy of less than $10 \mathrm{eV}$ are optimum for the dissociation of $\mathrm{O}_{2}$ in preference of $\mathrm{N}_{2}$ because a significant fraction of the input power is consumed by dissociation of $\mathrm{O}_{2}$. This suggests that most of $\mathrm{NO}$ would be converted into $\mathrm{NO}_{2}$ by the reaction with $\mathrm{O}(\mathrm{R} 28)$ in the presence of $\mathrm{O}_{2}$.

In addition, the similar selectivity of electron collision reactions R38 and R39 indicates that the branch ratio for $\mathrm{N}\left({ }^{4} \mathrm{~S}\right)$ and $\mathrm{N}\left({ }^{2} \mathrm{D}\right)$ formation through electron collision reactions with $\mathrm{N}_{2}$ is approximately one, which is consistent with the results reported by Cosby, ${ }^{39}$ who found that e $+\mathrm{N}_{2} \rightarrow \mathrm{N}\left({ }^{4} \mathrm{~S}\right)+\mathrm{N}\left({ }^{2} \mathrm{D}\right)$ is the dominant dissociation mechanism. In hindsight, the similar nitrogen reaction selectivities suggest that this single reaction could be used to replace both R38 and R39 to decrease the number of parameters in the model by two. Evaluation of the model 
with only four parameters ( $\alpha$ and $\beta$ for each of the electron collision reactions, R37 and e $+\mathrm{N}_{2}$ $\left.\rightarrow \mathrm{N}\left({ }^{4} \mathrm{~S}\right)+\mathrm{N}\left({ }^{2} \mathrm{D}\right)\right)$ confirmed that such a model is as accurate as the six parameter model.

\section{Critical $\mathrm{O}_{2}$ concentration for $\mathrm{NO}_{\mathrm{x}}$ formation and conversion}

The reaction mechanism of $\mathrm{NO}_{\mathrm{x}}$ conversion in the presence of oxygen, shown in Table 4, suggests that $\mathrm{NO}$ is converted to $\mathrm{N}_{2}$ and $\mathrm{O}_{2}$ through reduction with $\mathrm{N}\left({ }^{4} \mathrm{~S}\right)$ and $\mathrm{N}\left({ }^{2} \mathrm{D}\right)(\mathrm{R} 48$ and R56) and is formed through oxidation with $\mathrm{N}\left({ }^{2} \mathrm{D}\right)(\mathrm{R} 6)$. Therefore, the $\mathrm{O}_{2}$ concentration at which the production of NO by $N\left({ }^{2} \mathrm{D}\right)$ counterbalances the reduction of $\mathrm{NO}$ by $\mathrm{N}\left({ }^{4} \mathrm{~S}\right)$ and $\mathrm{N}\left({ }^{2} \mathrm{D}\right)$ is a critical value. Figure 9 shows an example of the lumped model calculation results, in which the $\mathrm{NO}_{\mathrm{x}}$ conversion, defined in Eq. (2), changes as a function of oxygen concentration for an inlet concentration of $350 \mathrm{ppm}$ NO at different specific energy inputs. The same model parameters as those discussed in the previous section were used in this calculation for the three electron collision reactions R37-R39 (Figure 5). $\mathrm{NO}_{\mathrm{x}}$ conversion of zero implies that the reduction of $\mathrm{NO}$ to $\mathrm{N}_{2}$ and $\mathrm{O}_{2}$ is counterbalanced by the formation of $\mathrm{NO}$, resulting in a constant total $\mathrm{NO}_{\mathrm{x}}$ concentration in the reactor. The results in Figure 9 show that the $\mathrm{NO}_{\mathrm{x}}$ conversion for all specific energy inputs converges to zero at almost the same oxygen concentration ( 2.5\%), which is consistent with the previous experimental observation (Figure 3(d)). At lower oxygen concentrations, $\mathrm{NO}_{\mathrm{x}}$ conversion is positive, which means that $\mathrm{NO}$ is being converted to $\mathrm{N}_{2}$ and $\mathrm{O}_{2}$ faster than it is being produced. At higher oxygen concentrations, $\mathrm{NO}_{\mathrm{x}}$ conversion is negative, which means that NO is formed through reaction R6 faster than it is decomposed. The oxygen concentration at which $\mathrm{NO}_{\mathrm{x}}$ conversion is zero is defined as the critical oxygen concentration.

Figure 9 shows that, in general, at a given specific energy input, $\mathrm{NO}_{\mathrm{x}}$ conversion initially decreases with increasing oxygen concentration and reaches a minimum negative value (i.e., when the $\mathrm{NO}_{\mathrm{x}}$ formation rate is maximum). This minimum in $\mathrm{NO}_{\mathrm{x}}$ conversion occurs because 
the rate of R6 is controlled by the concentration of both $\mathrm{O}_{2}$ and $\mathrm{N}\left({ }^{2} \mathrm{D}\right)$. At low oxygen concentrations, the effect of increasing oxygen concentration is dominant. However, increasing oxygen concentration causes the nitrogen concentration to decrease, which leads to a decrease of the $\left.\mathrm{N}^{2} \mathrm{D}\right)$ concentration. When the increase in oxygen concentration is unable to compensate for the decrease in $\mathrm{N}\left({ }^{2} \mathrm{D}\right.$ ) concentration (at $\mathrm{O}_{2}$ mole fractions of about 0.13 ), the observed minimum in $\mathrm{NO}_{\mathrm{x}}$ conversion occurs.

The consumption of $N\left({ }^{2} \mathrm{D}\right)$ occurs predominantly through R6, R56 and R58. The rate of R57 is negligible because the concentration of $\mathrm{N}_{2} \mathrm{O}$ is very low, as shown in Figure 4(c). At oxygen concentrations below the critical concentration, reactions R56 and R58 prevail, resulting in net NO conversion. However, at oxygen concentrations above the critical concentration, R6 prevails, resulting in net NO formation. The formation rate of $\mathrm{N}\left({ }^{2} \mathrm{D}\right)$ increases with increasing specific energy input, as shown in Eq.6(c). Therefore, at a given oxygen concentration, $\mathrm{NO}_{\mathrm{x}}$ conversion increases with increasing specific energy input below the critical concentration, while $\mathrm{NO}_{\mathrm{x}}$ conversion decreases (corresponding to $\mathrm{NO}_{\mathrm{x}}$ formation) with increasing specific energy input above the critical concentration, as shown in Figure 9.

Figure 10 shows the critical oxygen concentration as a function of initial NO concentration modeled at six specific energy inputs. The critical oxygen concentration increases with initial NO concentration. Consumption of $\mathrm{N}\left({ }^{2} \mathrm{D}\right)$ by NO conversion through R56 increases with initial NO concentration, which results in a decrease of $N\left({ }^{2} \mathrm{D}\right)$ consumption to form $\mathrm{NO}$ through R6. Therefore, higher oxygen concentrations are required to increase the reaction rate of R6 in order to counterbalance the reaction rate of R56. Figure 10 also shows that the critical concentrations for different specific energy inputs at the same initial NO concentration are approximately equal, which is consistent with the convergence point shown in Figure 9. 


\section{Conclusions}

In general, oxygen reduces $\mathrm{NO}_{\mathrm{x}}$ conversion and increases its formation in a pulsed corona discharge reactor. Ozone and nitrogen oxides other than $\mathrm{NO}, \mathrm{NO}_{2}$ and $\mathrm{N}_{2} \mathrm{O}$ are not detected at the outlet of the reactor in our experiments. $\mathrm{NO}$ is mainly converted to $\mathrm{NO}_{2}$ by chemical oxidation in the presence of oxygen. Initial selectivity analysis shows that three electron collision reactions are important for $\mathrm{NO}_{\mathrm{x}}$ reactions in $\mathrm{O}_{2} / \mathrm{N}_{2}$, although subsequent analysis shows that only two are required to accurately model the system. The rate constants of these electron collision reactions, calculated for different oxygen concentrations from a kinetic model, decrease with increasing oxygen concentration. The rate constant of $\mathrm{O}_{2}$ dissociation by electron collision reaction is almost two orders of magnitude higher than that of $\mathrm{N}_{2}$ dissociation by electron collision because oxygen has a lower dissociation energy compared to nitrogen. A reaction mechanism proposed for $\mathrm{NO}_{\mathrm{x}}$ conversion and formation in $\mathrm{O}_{2}$ and $\mathrm{N}_{2}$ plasma leads to a good agreement between the model data and experimental data. $\mathrm{NO}$ is converted to $\mathrm{N}_{2}$ and $\mathrm{O}_{2}$ through reduction reactions and is formed through an oxidation reaction in the presence of oxygen in the PCDR. The mechanism of NO formation occurs mainly by the reaction of $N\left({ }^{2} \mathrm{D}\right)$ radicals with molecular oxygen: $\left.\mathrm{N}^{2} \mathrm{D}\right)+\mathrm{O}_{2} \rightarrow \mathrm{NO}+\mathrm{O}$. The critical oxygen concentration, which is defined as the oxygen concentration with zero net $\mathrm{NO}_{\mathrm{x}}$ conversion, increases with increasing initial $\mathrm{NO}$ concentration.

\section{Acknowledgments}

This work was funded by the National Science Foundation (CTS - 9810040; CTS 0078700) and the Department of Defense (ARO-DAAD19-01-1-0488). The matching support 
was provided by the Research Office, University of Wyoming. The authors also gratefully acknowledge experimental assistance provided by Dr. S. Legowski and Mr. R. Borgialli.

\section{Literature cited}

1 Raether H. Electron Avalanches and Breakdown in Gases. Washington: Butterworths, 1964.

2 Sathiamoorthy G, Kalyana S, Finney WC, Clark RJ, Locke BR. Chemical Reaction Kinetics and Reactor Modeling of NOx Removal in a Pulsed Streamer Corona Discharge Reactor. Ind. Eng. Chem. Res. 1999; 38:1844-1855.

3 Zhou Q, Yao SC, Russell A, Boyle J. Flue gas nitrogen oxide (NOx) reduction using ammonia radical injection. J. Air Waste Manage. Assoc. 1992; 42:1193-1197.

4 Zhao G-B, Hu X, Argyle MD, Radosz M. N Atom Radicals and $\mathrm{N}_{2}\left(\mathrm{~A}^{3} \Sigma_{\mathrm{u}}^{+}\right)$Found to be Responsible for Nitrogen Oxides Conversion in Non-thermal Nitrogen Plasma. Ind. Eng. Chem. Res. 2004; 43:5077-5088.

5 Zhao G-B, Hu X, Yeung MC, Plumb OA, Radosz M. Nonthermal Plasma Reactions of Dilute Nitrogen Oxide Mixtures: NOx in Nitrogen. Ind. Eng. Chem. Res. 2004; 43:2315-2323.

6 Penetrante BM, Hsiao MC, Merritt BT, Vogtlin GE, Wallman PH. Comparison of Electrical Discharge Techniques for Nonthermal Plasma Processing of $\mathrm{NO}$ in $\mathrm{N}_{2}$. IEEE Trans. Plasma Sci. 1995; 23:679-687.

7 Herron JT. Modeling Studies of the Formation and Destruction of NO in Pulsed Barrier Discharges in Nitrogen and Air. Plasma Chem. Plasma Process. 2001; 21:581-609.

8 Yan K, Kanazawa S, Ohkubo T, Nomoto Y. Oxidation and Reduction Processes During NOx Removal with Corona-Induced Nonthermal Plasma. Plasma Chem. Plasma Process. 1999; 19:421-443.

9 Zhao G-B, Garikipati SVBJ, Hu X, Argyle MD, Radosz M. Effect of Reactor Configuration on NO Conversion in Non-thermal Plasma Reactors. AIChE J. 2004, (accepted).

10 Dinelli G, Civitano L, Rea M. Industrial Experiments on Pulse Corona Simultaneous Removal of NOx and $\mathrm{SO}_{2}$ from Flue Gas. IEEE Trans. Ind. Appl. 1990; 26:535-541.

11 Miller TM. Electron Affinities. In CRC Handbook of Chemistry and Physics, Lide DR. Ed. CRC Press: Boca Raton, 2003; p10-147.

12 Lofthus A, Krupenie PH. The Spectrum of Molecule Nitrogen. J. Phys. Chem. Ref. Data 1977; 6:113-307. 
13 Kanazawa S, Chang JS, Round GF, Sheng G, Ohkubo T, Nomoto Y, Adachi T. Removal of NOx from flue gas by corona discharge activated methane radical showers. J. Electrostatics 1997; 40 \& 41:651-656.

14 Mok YS, Kim JH, Nam IS, Ham SW. Removal of NO and Formation of Byproducts in a Positive-Pulsed Corona Discharge Reactor. Ind. Eng. Chem. Res. 2000; 39:3938-3944.

15 Gallimberti I. Impulse corona simulation for flue gas treatment. Pure Appl. Chem. 1988; 60:663-674.

16 Kerr JA. Strengths of Chemical Bonds. In CRC Handbook of Chemistry and Physics, Lide DR. Ed. CRC Press: Boca Raton, 2003; p9-56.

17 McLarnon CR, Penetrante BM. Effect of Gas Composition on the NOx Conversion Chemistry in a Plasma. SAE Technical Papers 982433 1998; 1-12.

18 Tas MA, van Hardeveld R, van Veldhuizen EM. Reactions of NO in a Positive Streamer Corona Plasma. Plasma Chem. Plasma Process. 1997; 17:371-391.

19 Takaki K, Jani MA, Fujiwara T. Removal of Nitric Oxide in Flue Gases by Multipoint to Plane Dielectric Barrier Discharge. IEEE Trans. Plasma Sci. 1999; 27:1137-1145.

20 Aritoshi K, Fujiwara M, Ishida M. Production and Removal Mechanisms of Discharge NOx Treatment in $\mathrm{N}_{2} / \mathrm{O}_{2}$ Gas Mixture. Jpn. J. Appl. Phys. 2002; 41:3936-3942.

21 Penetrante BM, Bardsley JN, Hsiao MC. Kinetic analysis of non-thermal plasmas used for pollution control. Jpn. J. Appl. Phys. 1997; 36:5007-5017.

22 Gentile AC, Kushner MJ. Microstreamer dynamics during plasma remediation of NO using atmospheric pressure dielectric barrier discharges. J. Appl. Phys. 1996; 79:3877-3885.

23 Gentile AC, Kushner MJ. Reaction chemistry and optimization of plasma remediation of NxOy from gas streams. J. Appl. Phys. 1995; 78:2074-2085.

24 Kim DJ, Choi Y, Kim KS. Effects of Process Variables on NOx Conversion by Pulsed Corona Discharge Process. Plasma Chem. Plasma Process. 2001; 21:625-650.

25 Lowke JJ, Morrow R. Theoretical Analysis of Removal of Oxides of Sulphur and Nitrogen in Pulsed Operation of Electrostatic Precipitators. IEEE Trans. Plasma Sci. 1995; 23:661-671.

26 Mukkavilli S, Lee CK, Varghese K, Tavlarides LL. Modeling of the Electrostatic Corona Discharge Reactor. IEEE Trans. Plasma Sci. 1988; 16:652-660.

27 Orlandini I, Riedel U. Chemical kinetics of NO removal by pulsed corona discharges. J. Phys. D: Appl. Phys. 2000; 33:2467-2474. 
$28 \mathrm{Hu} \mathrm{X}$, Nicholas J, Zhang JJ, Linjewile TM, de Filippis P, Agarwal PK. The Destruction of $\mathrm{N}_{2} \mathrm{O}$ in a Pulsed Corona Discharge Reactor. Fuel 2002; 81:1259-1268.

29 Schweitzer F, Mirabel P, George C. Multiphase chemistry of $\mathrm{N}_{2} \mathrm{O}_{5}, \mathrm{ClNO}_{2}$, and $\mathrm{BrNO}_{2}$. $J$. Phys. Chem. A 1998; 102:3942-3952.

30 Vogtlin GE. Pulsed Corona Discharge for Removal of NOx from Flue Gas. In Non-Thermal Plasma Techniques for Pollution Control-Part B: Electron Beam and Electrical Discharge, Penetrante BM, Schultheis SE. Ed. Springer-Verlag: Berlin, Heidelberg, 1993; G34, Part B:187-198.

31 Herron JT, Green DS. Chemical Kinetics Database and Predictive Schemes for Nonthermal Humid Air Plasma Chemistry. Part II. Neutral Species Reactions. Plasma Chem. Plasma Process. 2001; 21:459-481.

32 Piper LG. Energy transfer studies on $\mathrm{N}_{2}\left(\mathrm{X}^{1} \Sigma_{\mathrm{g}}{ }^{+}, \mathrm{v}\right)$ and $\mathrm{N}_{2}\left(\mathrm{~B}^{3} \Pi g\right)$. J. Chem. Phys. 1992; 97: 270-275.

33 Smirnov SA. Rybkin VV, Kholodkov IV, Titov VA. Simulation of the processes of formation and dissociation of neutral particles in air plasma: kinetics of neutral components. High Temp. 2002; 40:323-330.

34 Piper LG. Quenching Rate Coefficients for $\mathrm{N}_{2}\left(\mathrm{a}^{\prime 1} \Sigma_{\mathrm{u}}{ }^{-}\right)$. J. Chem. Phys. 1987; 87:1625-1629.

35 Marinelli WJ, Kessler WJ, Green BD, Blumberg WAM. Quenching of $\mathrm{N}_{2}\left(\mathrm{a}^{1} \Pi_{\mathrm{g}}, \mathrm{v}^{\prime}=0\right)$ by $\mathrm{N}_{2}$, $\mathrm{O}_{2}, \mathrm{CO}, \mathrm{CO}_{2}, \mathrm{CH}_{4}, \mathrm{H}_{2}$, and Ar. J. Chem. Phys. 1989; 90:2167-2173.

36 Herron JT. Evaluated Chemical Kinetics Data for Reactions of $\mathrm{N}\left({ }^{2} \mathrm{D}\right), \mathrm{N}\left({ }^{2} \mathrm{P}\right)$, and $\mathrm{N}_{2}\left(\mathrm{~A}^{3} \Sigma_{\mathrm{u}}{ }^{+}\right)$ in the Gas Phase. J. Phys. Chem. Ref. Data 1999; 28:1453-1483.

37 Fernandez A, Goumri A, Fontijn A. Kinetics of the Reactions of $\mathrm{N}\left({ }^{4} \mathrm{~S}\right)$ Atoms with $\mathrm{O}_{2}$ and $\mathrm{CO}_{2}$ over Wide Temperatures Ranges. J. Phys. Chem. A. 1998; 102:168-172.

38 Atkinson R, Baulch DL, Cox RA, Hampson JRF, Kerr JA, Troe J. Evaluated Kinetic and Photochemical Data for Atmospheric Chemistry: Supplement III. J. Phys. Chem. Ref. Data 1989; 18:881-1097.

39 Cosby PC. Electron-impact Dissociation of Nitrogen. J. Chem. Phys. 1993; 98:9544-9553.

40 Hill RD, Rahmim I, Rinker RG. Experimental Study of the Production of $\mathrm{NO}, \mathrm{N}_{2} \mathrm{O}$, and $\mathrm{O}_{3}$ in a Simulated Atmospheric Corona. Ind. Eng. Chem. Res. 1988; 27:1264-1269.

41 Krupenie PH. Spectrum of molecular oxygen. J. Phys. Chem. Ref. Data 1972; 1:423-534. 
42 Mok YS, Ham SW. Conversion of $\mathrm{NO}$ to $\mathrm{NO}_{2}$ in Air by a Pulsed Corona Discharge Process. Chem. Eng. Sci. 1998; 53:1667-1678.

43 Simek M, Babicky V, Clupek M, DeBenedictis S, Dilecce G, Sunka P. Excitation of $\mathrm{N}_{2}(\mathrm{C}$ $\left.{ }^{3} \Pi_{\mathrm{u}}\right)$ and $\mathrm{NO}\left(\mathrm{A}^{2} \Sigma^{+}\right)$states in a pulsed positive corona discharge in $\mathrm{N}_{2}, \mathrm{~N}_{2}-\mathrm{O}_{2}$ and $\mathrm{N}_{2}-\mathrm{NO}$ mixtures. J. Phys. D: Appl. Phys. 1998; 31:2591-2602.

44 Eliasson B, Kogelschatz U. Electron Impact Dissociation in Oxygen. J. Phys. B: At. Mol. Phys. 1986; 19:1241-1247.

45 http://gaphyor.lpgp.u-psud.fr/gaphyor.

46 http://kinetics.nist.gov/index.php.

47 Schofield K. Critically evaluated rate constants for gaseous reactions of several electronically excited species. J. Phys. Chem. Ref. Data 1979; 8:723-798.

48 Atkinson R, Baulch DL, Cox RA, Hampson JRF, Kerr JA, Rossi MJ, Troe J. Evaluated Kinetic and Photochemical Data for Atmospheric Chemistry: Supplement VI. J. Phys. Chem. Ref. Data 1997; 26:1329-1499.

49 Copeland RA, Knutsen K, Onishi ME, Yalcin T. Collisional removal of $\mathrm{O}_{2}\left(\mathrm{c}{ }^{1} \Sigma_{\mathrm{u}}^{-}, \mathrm{v}=9\right)$ by $\mathrm{O}_{2}, \mathrm{~N}_{2}$, and He. J. Chem. Phys. 1996; 105:10349-10355.

50 Kossyi IA, Kostinsky AY, Matveyev AA, Silakov VP. Kinetic Scheme of the Nonequilibrium Discharge in Nitrogen-Oxygen Mixtures. Plasma Sources Sci. Technol. 1992; 1: 207-220.

51 Kenner RD, Ogryzlo EA. Rate constant for the deactivation of molecular oxygen $\left(\mathrm{A}^{3} \Sigma_{\mathrm{u}}{ }^{+}\right)$by molecular nitrogen. Chem. Phys. Lett. 1983; 103:209-212.

52 Kenner RD, Ogryzlo EA. Deactivation of oxygen $\left(\mathrm{O}_{2}\left(\mathrm{~A}^{3} \Sigma_{\mathrm{u}}{ }^{+}\right)\right)$by molecular oxygen, atomic oxygen, and argon. Int. J. Chem. Kinet. 1980; 12:501-508.

53 Cosby PC. Electron-impact dissociation of oxygen. J. Chem. Phys. 1993; 98:9560-9569.

54 Barnett AJ, Marston G, Wayne RP. Kinetics and chemiluminescence in the reaction of nitrogen atoms with oxygen and ozone. J. Chem. Soc., Faraday Trans. 1987; 83:1453-63. 


\section{Table Captions}

Table 1. Experiments at $217 \mathrm{kPa}$

Table 2. Initial selectivity of consumption of active species of nitrogen by radiation, quenching, $\mathrm{O}_{2}$ dissociation and $\mathrm{NO}_{\mathrm{x}}$ conversion

Table 3. Chemical reactions and rate constants relevant to active species of oxygen

Table 4. Chemical reactions and rate constants for $\mathrm{NO}_{\mathrm{x}}$ in $\mathrm{N}_{2} / \mathrm{O}_{2}$ 
Table 1. Experiments at $217 \mathrm{kPa}$

\begin{tabular}{|c|c|c|}
\hline System & Flowrate $\left(\mathrm{m}^{3} / \mathrm{s}\right)$ & Residence time (s) \\
\hline $659 \mathrm{ppm} \mathrm{NO}+\mathrm{N}_{2}$ & $1.81 \times 10^{-4}$ & 20.8 \\
\hline $2.28 \% \mathrm{O}_{2}+355 \mathrm{ppm} \mathrm{NO}+\mathrm{N}_{2}$ & $2.64 \times 10^{-4}$ & 14.3 \\
\hline $4.60 \% \mathrm{O}_{2}+358 \mathrm{ppm} \mathrm{NO}+\mathrm{N}_{2}$ & $2.54 \times 10^{-4}$ & 14.8 \\
\hline $7.07 \% \mathrm{O}_{2}+428 \mathrm{ppm} \mathrm{NO}+\mathrm{N}_{2}$ & $2.58 \times 10^{-4}$ & 14.8 \\
\hline $13.6 \% \mathrm{O}_{2}+437 \mathrm{ppm} \mathrm{NO}+\mathrm{N}_{2}$ & $2.54 \times 10^{-4}$ & 14.9 \\
\hline
\end{tabular}

Table 2. Initial selectivity of consumption of active species of nitrogen by radiation, quenching, $\mathrm{O}_{2}$ dissociation and $\mathrm{NO}_{\mathrm{x}}$ conversion

\begin{tabular}{|c|c|c|c|c|c|c|c|c|}
\hline $\begin{array}{c}\text { Active } \\
\text { species }\end{array}$ & $\mathrm{k}_{\mathrm{I}}\left(\mathrm{s}^{-1}\right)$ & $\mathrm{k}_{\mathrm{q}} \mathrm{C}_{\mathrm{N} 2}\left(\mathrm{~s}^{-1}\right)$ & $\mathrm{k}_{\mathrm{d}} \mathrm{C}_{\mathrm{O} 2}\left(\mathrm{~s}^{-1}\right)$ & $\mathrm{k}_{\mathrm{r}} \mathrm{C}_{\mathrm{NOx}}\left(\mathrm{s}^{-1}\right)$ & $\mathrm{S}_{\mathrm{I}}(\%)$ & $\mathrm{S}_{\mathrm{q}}(\%)$ & $\mathrm{S}_{\mathrm{d}}(\%)$ & $\mathrm{S}_{\mathrm{r}}(\%)$ \\
\hline $\mathrm{N}_{2}\left(\mathrm{~A}^{3} \sum_{\mathrm{u}}^{+}\right)$ & 0.526 & 154 & $2.99 \times 10^{6}$ & $4.08 \times 10^{5}$ & $\sim 0$ & $\sim 0$ & 88.0 & $\sim 12.0$ \\
\hline $\mathrm{N}_{2}\left(\mathrm{~B}^{3} \prod_{\mathrm{g}}\right)$ & $2 \times 10^{5}$ & $1.54 \times 10^{9}$ & $2.38 \times 10^{8}$ & $1.26 \times 10^{7}$ & $\sim 0$ & 86.0 & 13.3 & 0.7 \\
\hline $\mathrm{N}_{2}\left(\mathrm{~B}^{\prime 3} \sum_{\mathrm{u}}^{-}\right)$ & $2.60 \times 10^{4}$ & $1.54 \times 10^{9}$ & $2.38 \times 10^{8}$ & $1.26 \times 10^{7}$ & $\sim 0$ & 86.0 & 13.3 & 0.7 \\
\hline $\mathrm{N}_{2}\left(\mathrm{a}^{\prime} \sum_{\mathrm{u}}^{-}\right)$ & 43.5 & $9.68 \times 10^{6}$ & $3.35 \times 10^{7}$ & $1.13 \times 10^{7}$ & $\sim 0$ & 17.8 & 61.5 & 20.7 \\
\hline $\mathrm{N}_{2}\left(\mathrm{a}^{1} \Pi_{\mathrm{g}}\right)$ & $1.80 \times 10^{4}$ & $1.12 \times 10^{9}$ & $5.13 \times 10^{8}$ & $1.13 \times 10^{7}$ & $\sim 0$ & 68.1 & 31.2 & 0.7 \\
\hline $\mathrm{N}_{2}\left(\mathrm{~W}^{1} \Delta_{\mathrm{u}}\right)$ & $6.50 \times 10^{2}$ & $5.11 \times 10^{8}$ & {$[-]$} & $1.13 \times 10^{7}$ & $\sim 0$ & 96.5 & {$[-]$} & 3.5 \\
\hline $\mathrm{N}_{2}\left(\mathrm{C}^{3} \Pi_{\mathrm{u}}\right)$ & $2.73 \times 10^{7}$ & $5.11 \times 10^{8}$ & $3.58 \times 10^{8}$ & {$[-]$} & 3.0 & 57.0 & 39.9 & {$[-]$} \\
\hline $\mathrm{N}_{2}\left(\mathrm{E}^{3} \sum_{\mathrm{g}}^{+}\right)$ & $5.26 \times 10^{3}$ & $5.11 \times 10^{8}$ & {$[-]$} & {$[-]$} & $\sim 0$ & 100 & {$[-]$} & {$[-]$} \\
\hline $\left.\mathrm{N}^{2} \mathrm{D}\right)$ & $1.07 \times 10^{-5}$ & $8.66 \times 10^{5}$ & $6.20 \times 10^{6}$ & $1.88 \times 10^{6}$ & $\sim 0$ & 9.7 & 69.3 & 21.0 \\
\hline $\left.\mathrm{N}^{4} \mathrm{~S}\right)$ & 0 & 0 & 118 & $9.74 \times 10^{5}$ & 0 & 0 & $\sim 0$ & 100 \\
\hline
\end{tabular}


Table 3. Chemical reactions and rate constants relevant to active species of oxygen

\begin{tabular}{|c|c|c|c|}
\hline Chemical reaction & Rate constant* & Source & No. \\
\hline \multicolumn{4}{|l|}{$\mathrm{O}_{2}\left(\mathrm{a}^{1} \Delta_{\mathrm{g}}\right)$ reactions } \\
\hline $\mathrm{O}_{2}\left(\mathrm{a}^{1} \Delta_{\mathrm{g}}\right) \rightarrow \mathrm{O}_{2}+\mathrm{h} v$ & $3.70 \times 10^{-4}$ & Schofield ${ }^{47}$ & R8 \\
\hline $\mathrm{O}_{2}\left(\mathrm{a}^{1} \Delta_{\mathrm{g}}\right)+\mathrm{N}_{2} \rightarrow \mathrm{O}_{2}+\mathrm{N}_{2}$ & $8.43 \times 10^{4}$ & Atkinson et al. ${ }^{48}$ & R9 \\
\hline $\mathrm{O}_{2}\left(\mathrm{a}^{1} \Delta_{\mathrm{g}}\right)+\mathrm{O}_{2} \rightarrow \mathrm{O}_{2}+\mathrm{O}_{2}$ & $9.63 \times 10^{5}$ & Atkinson et al. ${ }^{48}$ & $\mathrm{R} 10$ \\
\hline $\mathrm{O}_{2}\left(\mathrm{a}^{1} \Delta_{\mathrm{g}}\right)+\mathrm{NO} \rightarrow \mathrm{O}_{2}+\mathrm{NO}$ & $1.51 \times 10^{13}$ & Smirnov et al. ${ }^{33}$ & $\mathrm{R} 11$ \\
\hline \multicolumn{4}{|l|}{$\mathrm{O}_{2}\left(\mathrm{~b}^{1} \sum_{\mathrm{g}}^{+}\right)$reactions } \\
\hline $\mathrm{O}_{2}\left(\mathrm{~b}^{1} \sum_{\mathrm{g}}^{+}\right) \rightarrow \mathrm{O}_{2}+\mathrm{h} v$ & $9.09 \times 10^{-2}$ & Schofield ${ }^{47}$ & $\mathrm{R} 12$ \\
\hline $\mathrm{O}_{2}\left(\mathrm{~b}^{1} \sum_{\mathrm{g}}^{+}\right)+\mathrm{N}_{2} \rightarrow \mathrm{O}_{2}+\mathrm{N}_{2}$ & $1.26 \times 10^{9}$ & Atkinson et al. ${ }^{48}$ & $\mathrm{R} 13$ \\
\hline $\mathrm{O}_{2}\left(\mathrm{~b}^{1} \sum_{\mathrm{g}}^{+}\right)+\mathrm{O}_{2} \rightarrow \mathrm{O}_{2}+\mathrm{O}_{2}$ & $2.47 \times 10^{7}$ & Atkinson et al. ${ }^{48}$ & R14 \\
\hline $\mathrm{O}_{2}\left(\mathrm{~b}^{1} \sum_{\mathrm{g}}^{+}\right)+\mathrm{NO} \rightarrow \mathrm{O}_{2}+\mathrm{NO}$ & $2.41 \times 10^{10}$ & Smirnov et al. ${ }^{33}$ & $\mathrm{R} 15$ \\
\hline \multicolumn{4}{|l|}{$\mathrm{O}_{2}\left(\mathrm{c}^{1} \sum_{\mathrm{u}}\right)$ reactions } \\
\hline $\mathrm{O}_{2}\left(\mathrm{c}^{1} \sum_{\mathrm{u}}^{-}\right) \rightarrow \mathrm{O}_{2}+\mathrm{h} v$ & $10^{-4}$ & Schofield ${ }^{47}$ & $\mathrm{R} 16$ \\
\hline $\mathrm{O}_{2}\left(\mathrm{c}^{1} \sum_{\mathrm{u}}{ }^{-}\right)+\mathrm{N}_{2} \rightarrow \mathrm{O}_{2}+\mathrm{N}_{2}$ & $1.93 \times 10^{12}$ & Copeland et al. ${ }^{49}$ & R17 \\
\hline $\mathrm{O}_{2}\left(\mathrm{c}^{1} \sum_{\mathrm{u}}{ }^{-}\right)+\mathrm{O}_{2} \rightarrow \mathrm{O}_{2}+\mathrm{O}_{2}$ & $3.13 \times 10^{12}$ & Copeland et al. ${ }^{49}$ & $\mathrm{R} 18$ \\
\hline \multicolumn{4}{|l|}{$\mathrm{O}_{2}\left(\mathrm{C}^{3} \Delta_{\mathrm{u}}\right)$ reactions } \\
\hline $\mathrm{O}_{2}\left(\mathrm{C}^{3} \Delta_{\mathrm{u}}\right) \rightarrow \mathrm{O}_{2}+\mathrm{hv}$ & $10^{-5}$ & Schofield $^{47}$ & R19 \\
\hline $\mathrm{O}_{2}\left(\mathrm{C}^{3} \Delta_{\mathrm{u}}\right)+\mathrm{N}_{2} \rightarrow \mathrm{O}_{2}+\mathrm{N}_{2}$ & $1.81 \times 10^{11}$ & Kossyi et al..$^{50}$ & $\mathrm{R} 20$ \\
\hline $\mathrm{O}_{2}\left(\mathrm{C}^{3} \Delta_{\mathrm{u}}\right)+\mathrm{O}_{2} \rightarrow \mathrm{O}_{2}+\mathrm{O}_{2}$ & $1.75 \times 10^{11}$ & Kossyi et al. ${ }^{50}$ & $\mathrm{R} 21$ \\
\hline \multicolumn{4}{|l|}{$\mathrm{O}_{2}\left(\mathrm{~A}^{3} \sum_{\mathrm{u}}^{+}\right)$reactions } \\
\hline $\mathrm{O}_{2}\left(\mathrm{~A}^{3} \sum_{\mathrm{u}}^{+}\right) \rightarrow \mathrm{O}_{2}+\mathrm{hv}$ & 5 & Schofield ${ }^{47}$ & $\mathrm{R} 22$ \\
\hline $\mathrm{O}_{2}\left(\mathrm{~A}^{3} \sum_{\mathrm{u}}^{+}\right)+\mathrm{N}_{2} \rightarrow \mathrm{O}_{2}+\mathrm{N}_{2}$ & $5.60 \times 10^{9}$ & Kenner and Ogryzlo ${ }^{51}$ & $\mathrm{R} 23$ \\
\hline $\mathrm{O}_{2}\left(\mathrm{~A}^{3} \sum_{\mathrm{u}}^{+}\right)+\mathrm{O}_{2} \rightarrow \mathrm{O}_{2}+\mathrm{O}_{2}$ & $1.75 \times 10^{11}$ & Kenner and Ogryzlo ${ }^{52}$ & $\mathrm{R} 24$ \\
\hline $\mathrm{O}_{2}\left(\mathrm{~A}^{3} \sum_{\mathrm{u}}^{+}\right)+\mathrm{N}_{2} \mathrm{O} \rightarrow \mathrm{O}_{2}+\mathrm{N}_{2} \mathrm{O}$ & $2.83 \times 10^{12}$ & Schofield ${ }^{47}$ & $\mathrm{R} 25$ \\
\hline
\end{tabular}


$\mathrm{O}_{2}\left(\mathrm{~B}^{3} \sum_{\mathrm{u}}{ }^{-}\right)$reactions

$\mathrm{O}_{2}\left(\mathrm{~B}^{3} \sum_{\mathrm{u}}{ }^{-}\right) \rightarrow \mathrm{O}_{2}+\mathrm{hv}$

$2.50 \times 10^{7}$

Schofield $^{47}$

R26

$\mathrm{O}\left({ }^{3} \mathrm{P}\right)$ reactions

$\mathrm{O}\left({ }^{3} \mathrm{P}\right)+\mathrm{O}_{2} \rightarrow \mathrm{O}_{3}$

$1.76 \times 10^{10}$

Atkinson et al. ${ }^{48}$

R27

$\mathrm{O}\left({ }^{3} \mathrm{P}\right)+\mathrm{NO} \rightarrow \mathrm{NO}_{2}$

$2.45 \times 10^{12}$

Atkinson et al. ${ }^{48}$

R28

$\mathrm{O}\left({ }^{3} \mathrm{P}\right)+\mathrm{NO}_{2} \rightarrow \mathrm{NO}_{3}$

$2.03 \times 10^{12}$

Atkinson et al. ${ }^{48}$

R29

$\mathrm{O}\left({ }^{1} \mathrm{D}\right)$ reactions

$\mathrm{O}\left({ }^{1} \mathrm{D}\right) \rightarrow \mathrm{O}_{2}+\mathrm{hv}$

$6.76 \times 10^{-3}$

Cosby $^{53}$

R30

$\mathrm{O}\left({ }^{1} \mathrm{D}\right)+\mathrm{N}_{2} \rightarrow \mathrm{O}\left({ }^{3} \mathrm{P}\right)+\mathrm{N}_{2}$

$1.57 \times 10^{13}$

Herron and Green ${ }^{31}$

R31

$\mathrm{O}\left({ }^{1} \mathrm{D}\right)+\mathrm{O}_{2} \rightarrow \mathrm{O}\left({ }^{3} \mathrm{P}\right)+\mathrm{O}_{2}$

$2.41 \times 10^{13}$

Herron and Green ${ }^{31}$

R32

$\mathrm{O}\left({ }^{1} \mathrm{D}\right)+\mathrm{NO} \rightarrow$ products

$2.41 \times 10^{13}$

Herron and Green ${ }^{31}$

R33

$\mathrm{O}\left({ }^{1} \mathrm{D}\right)+\mathrm{NO}_{2} \rightarrow \mathrm{NO}+\mathrm{O}_{2}$

$8.43 \times 10^{13}$

Herron and Green ${ }^{31}$

R34

$\mathrm{O}\left({ }^{1} \mathrm{D}\right)+\mathrm{N}_{2} \mathrm{O} \rightarrow \mathrm{NO}+\mathrm{NO}$

$4.33 \times 10^{13}$

Herron and Green ${ }^{31}$

R35

$\mathrm{O}\left({ }^{1} \mathrm{D}\right)+\mathrm{N}_{2} \mathrm{O} \rightarrow \mathrm{N}_{2}+\mathrm{O}_{2}$

$2.65 \times 10^{13}$

Herron and Green ${ }^{31}$

R36

* The units of the rate constants are $\mathrm{s}^{-1}$ for radiation reactions and $\mathrm{cm}^{3} \cdot \mathrm{mol}^{-1} \cdot \mathrm{s}^{-1}$ for bimolecular reactions. 
Table 4. Chemical reactions and rate constants for $\mathrm{NO}_{\mathrm{x}}$ in $\mathrm{N}_{2} / \mathrm{O}_{2}$

\begin{tabular}{|c|c|c|c|}
\hline Chemical reaction & $\begin{array}{l}\text { Rate constant } \\
\left(\mathrm{cm}^{3} \cdot \mathrm{mol}^{-1} \cdot \mathrm{s}^{-1}\right)\end{array}$ & Source & No. \\
\hline $\mathrm{e}+\mathrm{O}_{2} \rightarrow \mathrm{O}\left({ }^{3} \mathrm{P}\right)+\mathrm{O}\left({ }^{3} \mathrm{P}\right)+\mathrm{e}$ & $k_{37}=\frac{\beta_{1}}{[e]} \sqrt{\frac{1}{\alpha_{1} P}} W^{0.75} \exp \left(-\frac{\alpha_{1} P}{W}\right)$ & This work & R37 \\
\hline $\mathrm{e}+\mathrm{N}_{2} \rightarrow \mathrm{N}\left({ }^{4} \mathrm{~S}\right)+\mathrm{N}\left({ }^{4} \mathrm{~S}\right)+\mathrm{e}$ & $k_{38}=\frac{\beta_{2}}{[e]} \sqrt{\frac{1}{\alpha_{2} P}} W^{0.75} \exp \left(-\frac{\alpha_{2} P}{W}\right)$ & This work & R38 \\
\hline $\mathrm{e}+\mathrm{N}_{2} \rightarrow \mathrm{N}\left({ }^{2} \mathrm{D}\right)+\mathrm{N}\left({ }^{2} \mathrm{D}\right)+\mathrm{e}$ & $k_{39}=\frac{\beta_{3}}{[e]} \sqrt{\frac{1}{\alpha_{3} P}} W^{0.75} \exp \left(-\frac{\alpha_{3} P}{W}\right)$ & This work & R39 \\
\hline $\mathrm{N}\left({ }^{4} \mathrm{~S}\right)+\mathrm{NO} \rightarrow \mathrm{N}_{2}+\mathrm{O}\left({ }^{3} \mathrm{P}\right)$ & $1.87 \times 10^{13}$ & Atkinson et al. ${ }^{38}$ & $\mathrm{R} 48$ \\
\hline $\mathrm{N}\left({ }^{4} \mathrm{~S}\right)+\mathrm{NO}_{2} \rightarrow \mathrm{N}_{2} \mathrm{O}+\mathrm{O}\left({ }^{3} \mathrm{P}\right)$ & $1.81 \times 10^{12}$ & Atkinson et al. ${ }^{38}$ & $\mathrm{R} 49$ \\
\hline $\mathrm{N}\left({ }^{4} \mathrm{~S}\right)+\mathrm{NO}_{2} \rightarrow \mathrm{N}_{2}+\mathrm{O}_{2}$ & $4.21 \times 10^{11}$ & Kossyi et al. $^{50}$ & $\mathrm{R} 50$ \\
\hline $\mathrm{N}\left({ }^{4} \mathrm{~S}\right)+\mathrm{NO}_{2} \rightarrow \mathrm{N}_{2}+2 \mathrm{O}\left({ }^{3} \mathrm{P}\right)$ & $5.48 \times 10^{11}$ & Kossyi et al. ${ }^{50}$ & R51 \\
\hline $\mathrm{N}\left({ }^{4} \mathrm{~S}\right)+\mathrm{NO}_{2} \rightarrow 2 \mathrm{NO}$ & $1.38 \times 10^{12}$ & Kossyi et al. ${ }^{50}$ & R52 \\
\hline $\mathrm{N}\left({ }^{4} \mathrm{~S}\right)+\mathrm{N}\left({ }^{4} \mathrm{~S}\right)+\mathrm{N}_{2} \rightarrow \mathrm{N}_{2}+\mathrm{N}_{2}$ & $1.59 \times 10^{15}\left[\mathrm{~N}_{2}\right]$ & Kossyi et al. ${ }^{50}$ & R53 \\
\hline $\mathrm{N}\left({ }^{4} \mathrm{~S}\right)+\mathrm{O}\left({ }^{3} \mathrm{P}\right)+\mathrm{N}_{2} \rightarrow \mathrm{NO}+\mathrm{N}_{2}$ & $3.68 \times 10^{15}\left[\mathrm{~N}_{2}\right]$ & Kossyi et al. ${ }^{50}$ & $\mathrm{R} 54$ \\
\hline $\mathrm{N}\left({ }^{4} \mathrm{~S}\right)+\mathrm{O}_{2} \rightarrow \mathrm{NO}+\mathrm{O}\left({ }^{3} \mathrm{P}\right)$ & $5.91 \times 10^{7}$ & Fernandez et al. ${ }^{37}$ & R7 \\
\hline $\mathrm{N}\left({ }^{4} \mathrm{~S}\right)+\mathrm{O}_{3} \rightarrow \mathrm{NO}+\mathrm{O}_{2}$ & $6.02 \times 10^{7}$ & Barnett et al. ${ }^{54}$ & R55 \\
\hline $\mathrm{N}\left({ }^{2} \mathrm{D}\right)+\mathrm{O}_{2} \rightarrow \mathrm{NO}+\mathrm{O}\left({ }^{3} \mathrm{P}\right)$ & $3.13 \times 10^{12}$ & Herron $^{36}$ & R6 \\
\hline $\mathrm{N}\left({ }^{2} \mathrm{D}\right)+\mathrm{NO} \rightarrow \mathrm{N}_{2}+\mathrm{O}\left({ }^{3} \mathrm{P}\right)$ & $3.61 \times 10^{13}$ & Herron $^{36}$ & R56 \\
\hline $\mathrm{N}\left({ }^{2} \mathrm{D}\right)+\mathrm{N}_{2} \mathrm{O} \rightarrow \mathrm{NO}+\mathrm{N}_{2}$ & $1.32 \times 10^{12}$ & Herron $^{36}$ & R57 \\
\hline $\mathrm{N}\left({ }^{2} \mathrm{D}\right)+\mathrm{N}_{2} \rightarrow \mathrm{N}+\mathrm{N}_{2}$ & $1.02 \times 10^{10}$ & Herron $^{36}$ & $\mathrm{R} 58$ \\
\hline $\mathrm{O}\left({ }^{3} \mathrm{P}\right)+\mathrm{O}_{2}+\mathrm{N}_{2} \rightarrow \mathrm{O}_{3}+\mathrm{N}_{2}$ & $2.03 \times 10^{14}\left[\mathrm{~N}_{2}\right]$ & Atkinson et al. ${ }^{48}$ & R59 \\
\hline $\mathrm{O}\left({ }^{3} \mathrm{P}\right)+\mathrm{O}_{2}+\mathrm{O}_{2} \rightarrow \mathrm{O}_{3}+\mathrm{O}_{2}$ & $2.17 \times 10^{14}\left[\mathrm{O}_{2}\right]$ & Atkinson et al. ${ }^{48}$ & R60 \\
\hline $\mathrm{O}\left({ }^{3} \mathrm{P}\right)+\mathrm{O}_{3} \rightarrow \mathrm{O}_{2}+\mathrm{O}_{2}$ & $4.82 \times 10^{9}$ & Atkinson et al. ${ }^{48}$ & R61 \\
\hline $\mathrm{O}\left({ }^{3} \mathrm{P}\right)+\mathrm{NO} \rightarrow \mathrm{NO}_{2}$ & $2.45 \times 10^{12}$ & Atkinson et al. ${ }^{48}$ & $\mathrm{R} 28$ \\
\hline $\mathrm{O}\left({ }^{3} \mathrm{P}\right)+\mathrm{NO}_{2} \rightarrow \mathrm{NO}_{3}$ & $2.03 \times 10^{12}$ & Atkinson et al. ${ }^{48}$ & R29 \\
\hline $\mathrm{O}\left({ }^{3} \mathrm{P}\right)+\mathrm{NO}_{2} \rightarrow \mathrm{NO}+\mathrm{O}\left({ }^{3} \mathrm{P}\right)$ & $5.85 \times 10^{12}$ & Atkinson et al. ${ }^{48}$ & R62 \\
\hline $\mathrm{O}\left({ }^{3} \mathrm{P}\right)+\mathrm{NO}_{3} \rightarrow \mathrm{NO}_{2}+\mathrm{O}_{2}$ & $1.02 \times 10^{13}$ & Atkinson et al. ${ }^{48}$ & R63 \\
\hline $\mathrm{O}\left({ }^{3} \mathrm{P}\right)+\mathrm{O}\left({ }^{3} \mathrm{P}\right)+\mathrm{N}_{2} \rightarrow \mathrm{O}_{2}+\mathrm{N}_{2}$ & $1.10 \times 10^{15}\left[\mathrm{~N}_{2}\right]$ & Kossyi et al. ${ }^{50}$ & R64 \\
\hline $\mathrm{NO}+\mathrm{O}_{3} \rightarrow \mathrm{NO}_{2}+\mathrm{O}_{2}$ & $1.08 \times 10^{10}$ & Atkinson et al. ${ }^{48}$ & R65 \\
\hline $\mathrm{NO}+\mathrm{NO}_{3} \rightarrow \mathrm{NO}_{2}+\mathrm{NO}_{2}$ & $1.57 \times 10^{13}$ & Atkinson et al. ${ }^{48}$ & R66 \\
\hline $\mathrm{NO}+\mathrm{NO}+\mathrm{O}_{2} \rightarrow \mathrm{NO}_{2}+\mathrm{NO}_{2}$ & $7.25 \times 10^{9}\left[\mathrm{O}_{2}\right]$ & Atkinson et al. ${ }^{48}$ & R67 \\
\hline $\mathrm{NO}_{2}+\mathrm{O}_{3} \rightarrow \mathrm{NO}_{3}+\mathrm{O}_{2}$ & $2.11 \times 10^{7}$ & Atkinson et al. ${ }^{48}$ & R68 \\
\hline
\end{tabular}




\section{Figure Captions}

Figure 1. Experimental set up

(1) gas cylinder, $\mathrm{NO}+\mathrm{N}_{2}$; (2) gas cylinder, $\mathrm{O}_{2}$ in $\mathrm{N}_{2}$; (3) valve; (4) rotameter; (5) pressure gague; (6) pulsed corona discharge reactor; (7) gas bomb; (8) gas chromatograph

Figure 2. FTIR spectra at $200 \mathrm{~Hz}$ showing the product distribution; (a) $659 \mathrm{ppm} \mathrm{NO}+\mathrm{N}_{2}$, (b) $4.60 \% \mathrm{O} 2+358 \mathrm{ppm} \mathrm{NO}+\mathrm{N}_{2}$

Figure 3. Experimental results

(a) $\mathrm{NO}$ evolution with specific energy input; (b) $\mathrm{NO}_{2}$ evolution with specific energy input;

(c) $\mathrm{N}_{2} \mathrm{O}$ evolution with specific energy input; (d) NOx conversion with specific energy input.

口: $659 \mathrm{ppm} \mathrm{NO}+\mathrm{N}_{2}$

$\mathrm{O}: 2.28 \% \mathrm{O}_{2}+355 \mathrm{ppm} \mathrm{NO}+\mathrm{N}_{2} ; \triangle: 4.60 \% \mathrm{O}_{2}+358 \mathrm{ppm} \mathrm{NO}+\mathrm{N}_{2}$

$\diamond: 7.07 \% \mathrm{O}_{2}+428 \mathrm{ppm} \mathrm{NO}+\mathrm{N}_{2} ; \times: 13.6 \% \mathrm{O}_{2}+437 \mathrm{ppm} \mathrm{NO}+\mathrm{N}_{2}$

Figure 4. Experimental data and correlated data for varying oxygen content.

(a) $2.28 \% \mathrm{O}_{2}+355 \mathrm{ppm} \mathrm{NO}+\mathrm{N}_{2}$, (b) $4.60 \% \mathrm{O}_{2}+358 \mathrm{ppm} \mathrm{NO}+\mathrm{N}_{2}$,

(c) $7.07 \% \mathrm{O}_{2}+428 \mathrm{ppm} \mathrm{NO}+\mathrm{N}_{2}$, (d) $13.6 \% \mathrm{O}_{2}+437 \mathrm{ppm} \mathrm{NO}+\mathrm{N}_{2}$

Experimental data: $\mathbf{\square}(\mathrm{NO}), \mathbf{O}\left(\mathrm{NO}_{2}\right), \boldsymbol{\Delta}\left(\mathrm{N}_{2} \mathrm{O}\right)$;

Calculated data: - $(\mathrm{NO}),---\left(\mathrm{NO}_{2}\right),-\cdot-\left(\mathrm{N}_{2} \mathrm{O}\right)$

Figure 5. Ozone conversion through reaction R65 as a function of residence time assuming 50 ppm NO in the gas.

Figure 6. Model parameters as a function of $\mathrm{O}_{2}$ concentration

Model parameter $\alpha$ for electron collision reactions (a); Model parameter $\beta$ for electron collision reaction R37 (b), R38 (c), R39 (d). () R37, (O) R38, ( $\mathbf{\Delta})$ R39, (-) regression results

Figure 7. Rate constants of electron collision reactions R37-R39 as a function of $\mathrm{O}_{2}$ concentration at $100 \mathrm{~W}$ power input (a); Ratio of rate constant of electron collision reaction with $\mathrm{O}_{2}$ and $\mathrm{N}_{2}$ as a function of $\mathrm{O}_{2}$ concentration at different power inputs (b)

Figure 8. Rates of electron collision reactions R37-R39 as a function of $\mathrm{O}_{2}$ concentration at 100 W power input (a); Selectivity of electron collision reactions R37-R39 as a function of $\mathrm{O}_{2}$ concentration at $100 \mathrm{~W}$ power input (b)

Figure 9. $\mathrm{NO}_{\mathrm{x}}$ conversion as a function of $\mathrm{O}_{2}$ concentration for inlet concentration of $350 \mathrm{ppm}$ $\mathrm{NO}$ at different specific energy input

Figure 10. Critical $\mathrm{O}_{2}$ concentration as a function of $\mathrm{NO}$ concentration at different specific energy input 


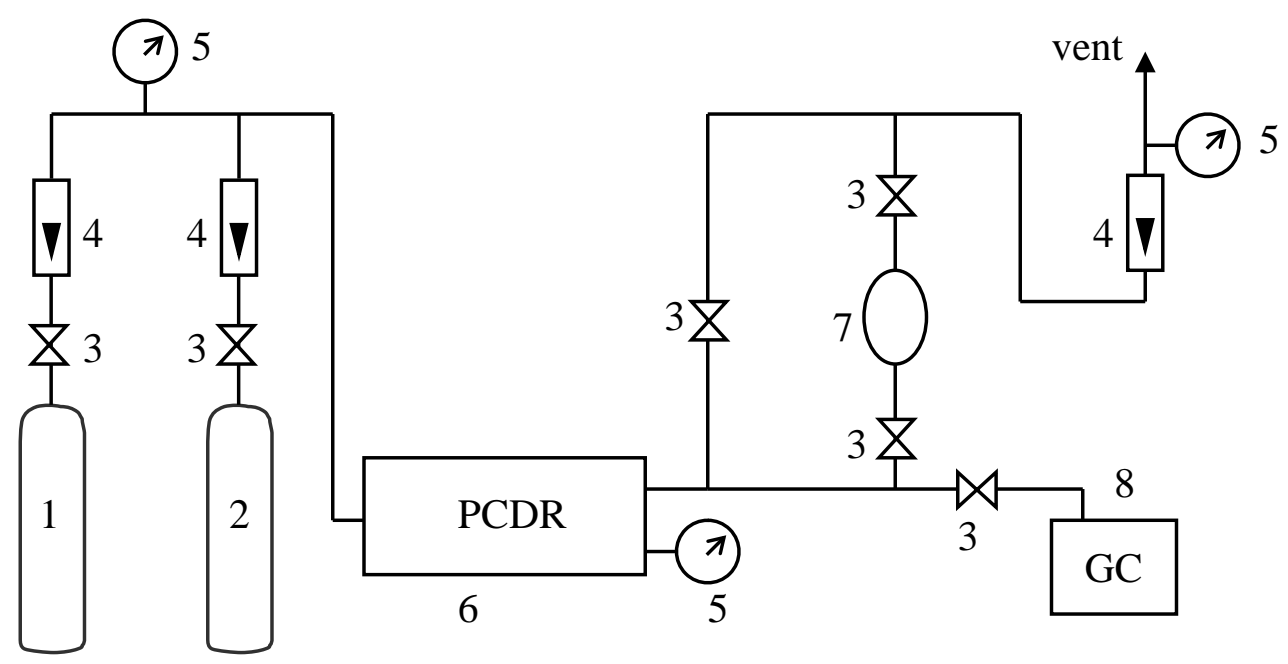

Figure 1. Experimental set up

(1) gas cylinder, $\mathrm{NO}+\mathrm{N}_{2}$; (2) gas cylinder, $\mathrm{O}_{2}$ in $\mathrm{N}_{2}$; (3) valve; (4) rotameter; (5) pressure gauge; (6) pulsed corona discharge reactor; (7) gas bomb; (8) gas chromatograph

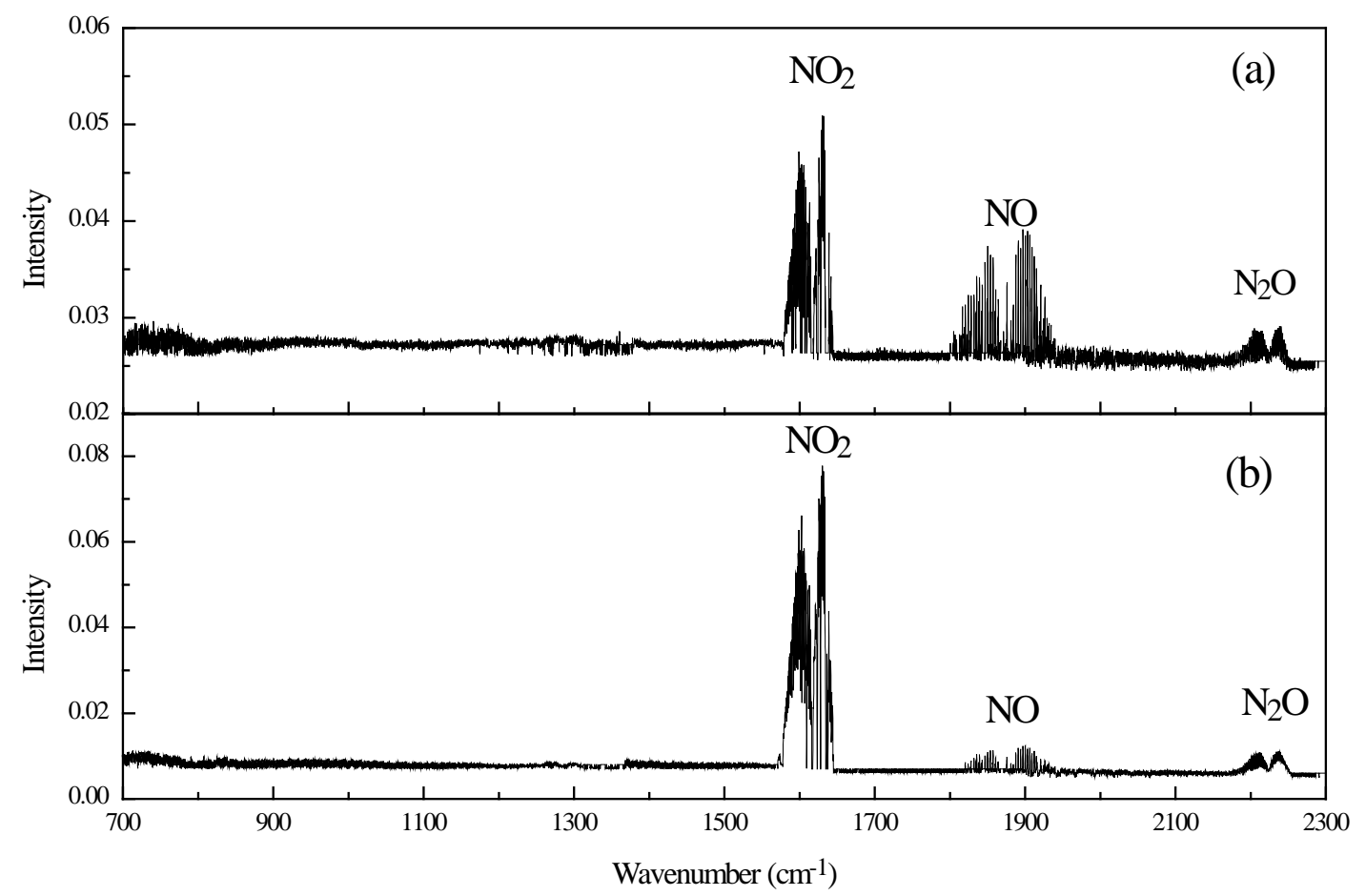

Figure 2. FTIR spectra at $200 \mathrm{~Hz}$ showing the product distribution; (a) $659 \mathrm{ppm} \mathrm{NO}+\mathrm{N}_{2}$, (b) $4.60 \% \mathrm{O}_{2}+358 \mathrm{ppm} \mathrm{NO}+\mathrm{N}_{2}$ 


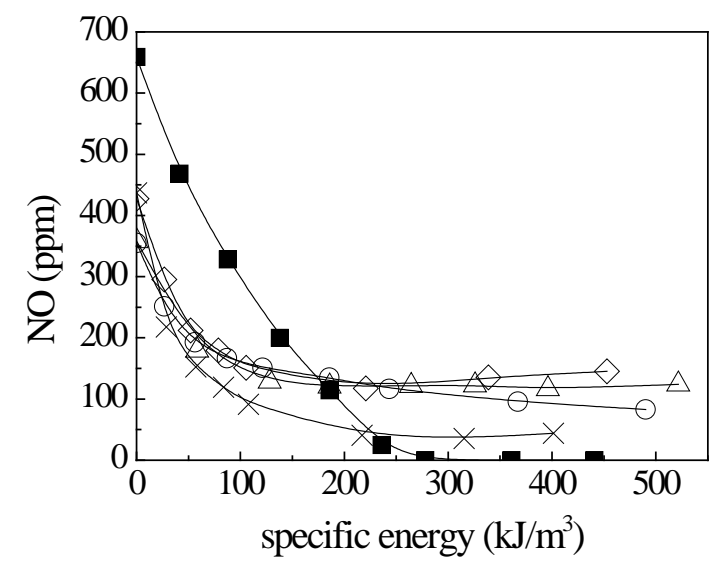

(a)

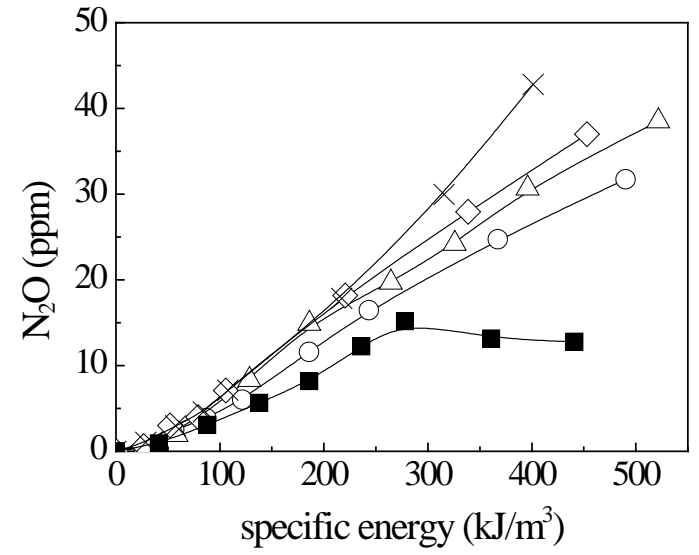

(c)

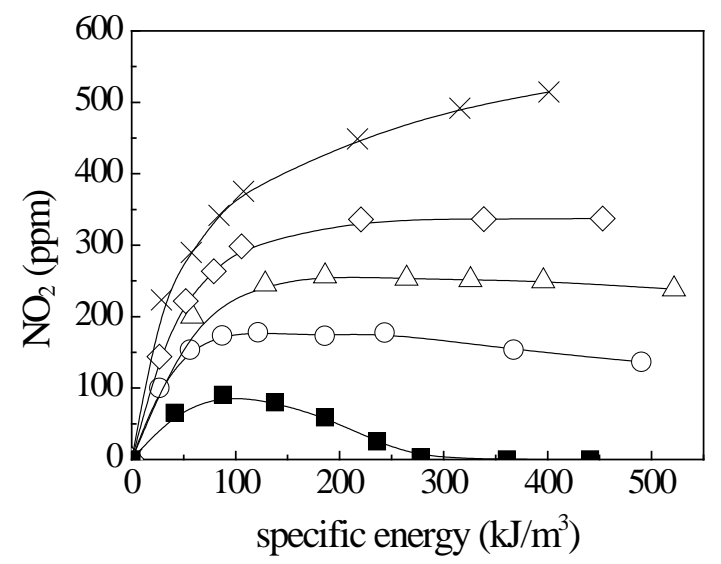

(b)

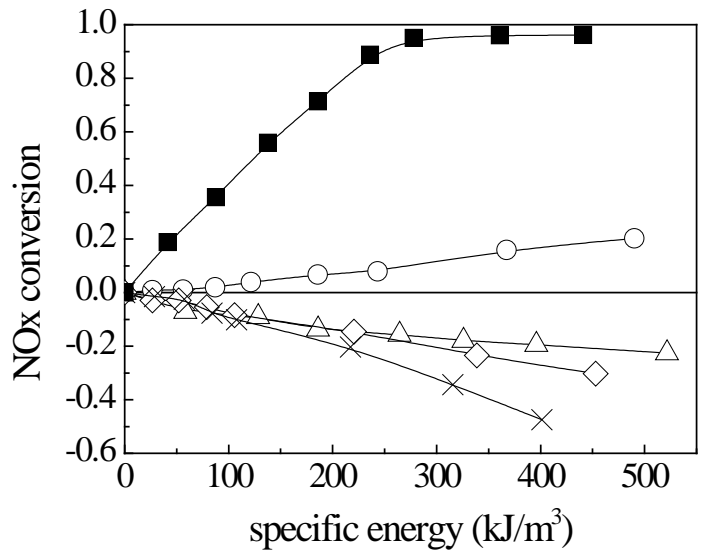

(d)

Figure 3. Experimental results

(a) $\mathrm{NO}$ evolution with specific energy input; (b) $\mathrm{NO}_{2}$ evolution with specific energy input; (c) $\mathrm{N}_{2} \mathrm{O}$ evolution with specific energy input; (d) NOx conversion with specific energy input.

口: $659 \mathrm{ppm} \mathrm{NO}+\mathrm{N}_{2}$

$\mathrm{O}: 2.28 \% \mathrm{O}_{2}+355 \mathrm{ppm} \mathrm{NO}+\mathrm{N}_{2} ; \triangle: 4.60 \% \mathrm{O}_{2}+358 \mathrm{ppm} \mathrm{NO}+\mathrm{N}_{2}$

$\diamond: 7.07 \% \mathrm{O}_{2}+428 \mathrm{ppm} \mathrm{NO}+\mathrm{N}_{2} ; \times: 13.6 \% \mathrm{O}_{2}+437 \mathrm{ppm} \mathrm{NO}+\mathrm{N}_{2}$ 


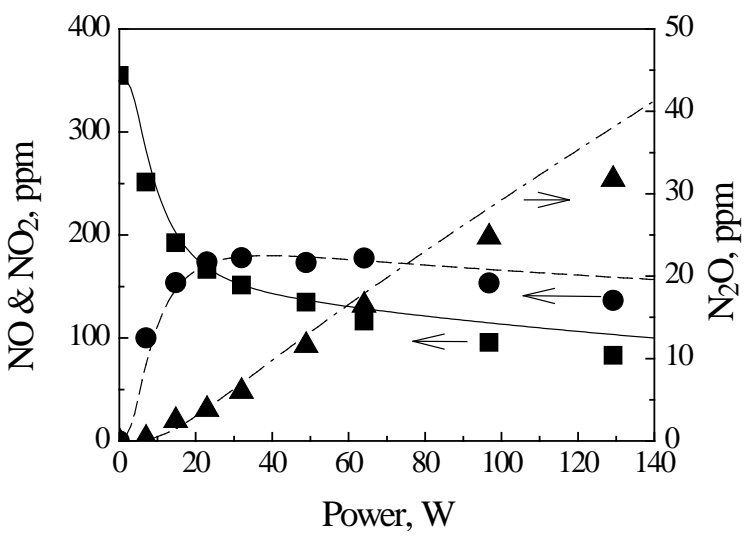

(a)

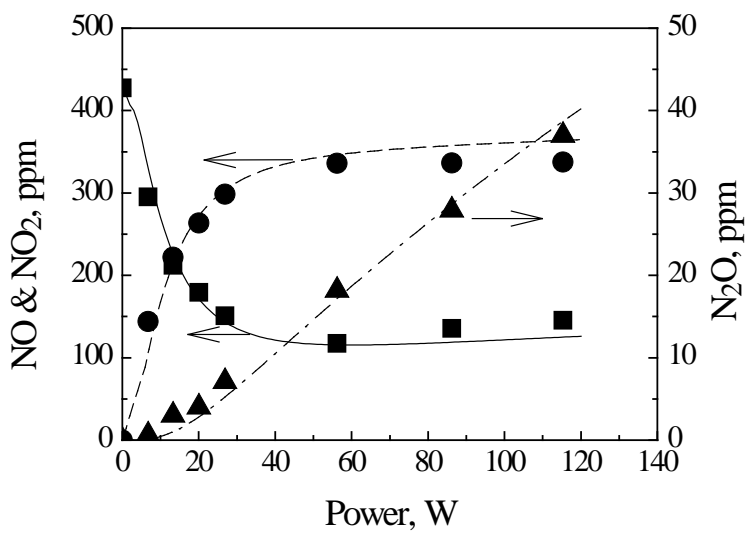

(c)

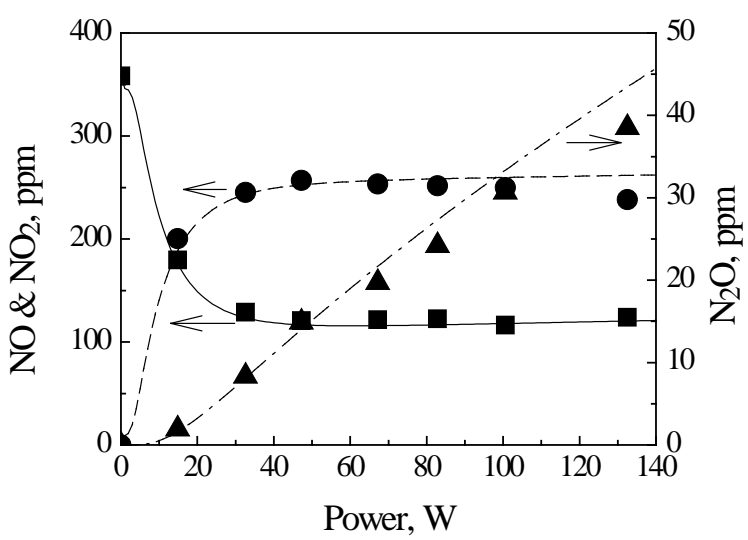

(b)

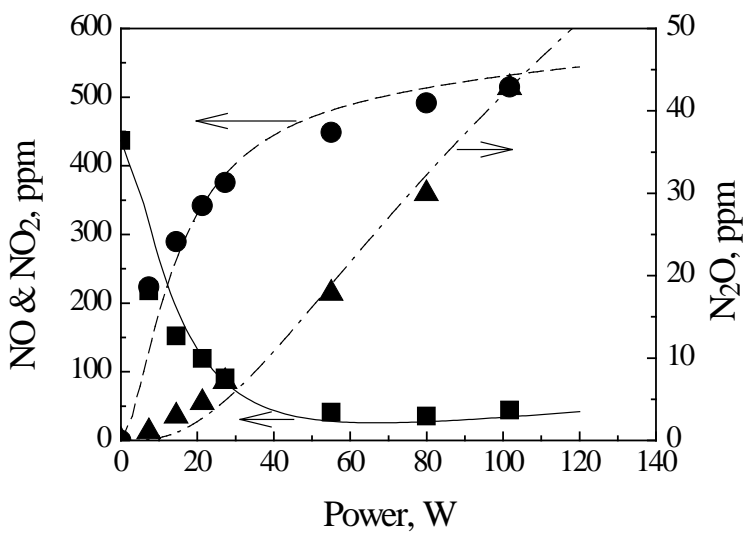

(d)

Figure 4. Experimental data and correlated data for varying oxygen content.

(a) $2.28 \% \mathrm{O}_{2}+355 \mathrm{ppm} \mathrm{NO}+\mathrm{N}_{2}$, (b) $4.60 \% \mathrm{O}_{2}+358 \mathrm{ppm} \mathrm{NO}+\mathrm{N}_{2}$,

(c) $7.07 \% \mathrm{O}_{2}+428 \mathrm{ppm} \mathrm{NO}+\mathrm{N}_{2}$, (d) $13.6 \% \mathrm{O}_{2}+437 \mathrm{ppm} \mathrm{NO}+\mathrm{N}_{2}$

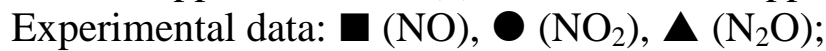

Calculated data: - (NO), --- $\left(\mathrm{NO}_{2}\right),-\cdot-\left(\mathrm{N}_{2} \mathrm{O}\right)$ 


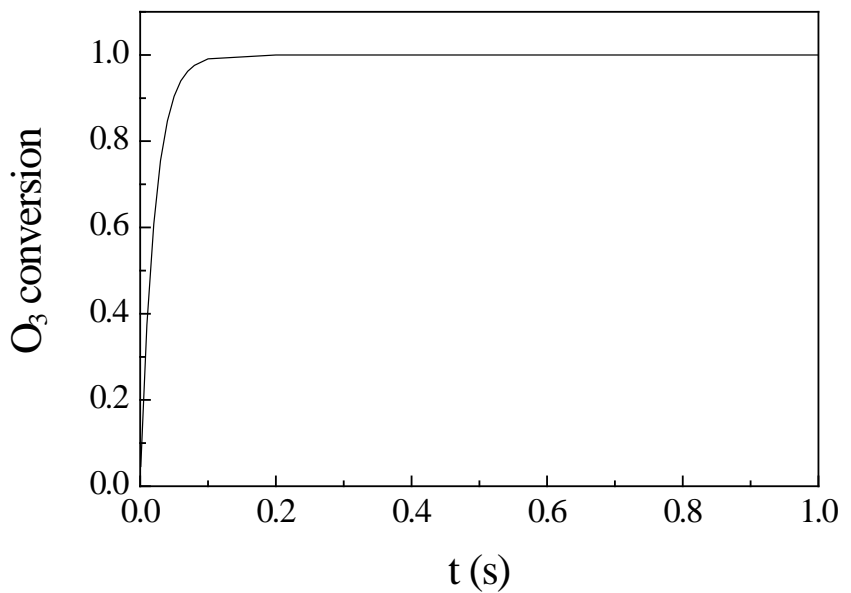

Figure 5. Ozone conversion through reaction R65 as a function of residence time assuming 50 ppm NO in the gas.

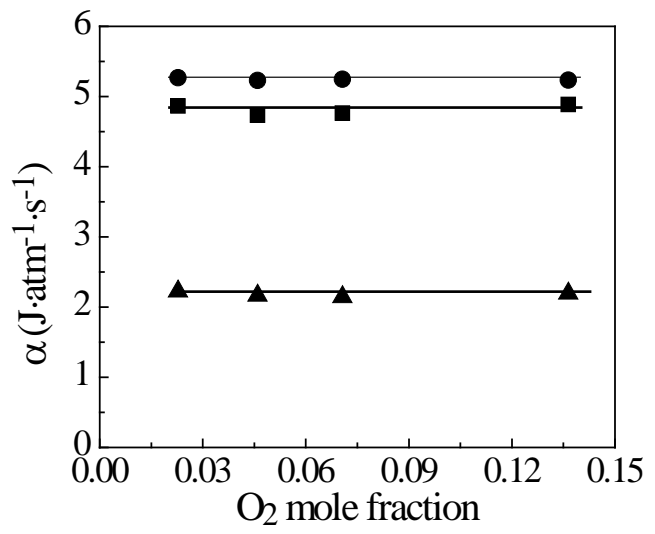

(a)

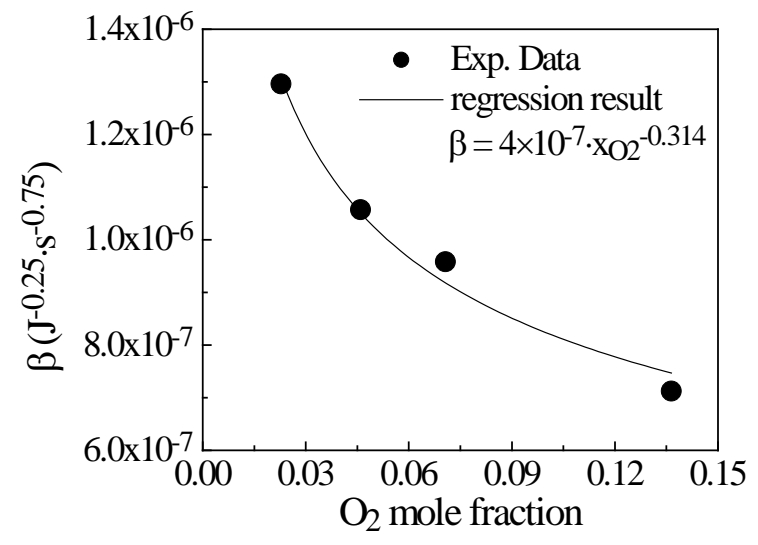

(c) e $+\mathrm{N}_{2} \rightarrow \mathrm{N}\left({ }^{4} \mathrm{~S}\right)+\mathrm{N}\left({ }^{4} \mathrm{~S}\right)+\mathrm{e}$

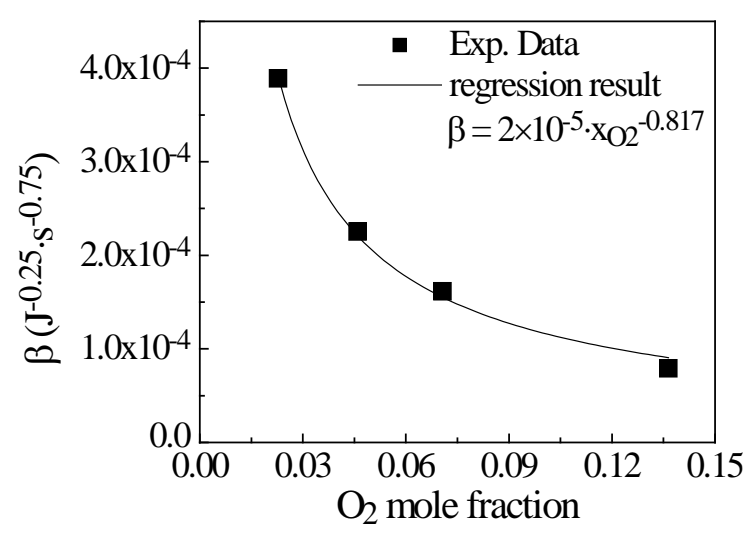

(b) $\mathrm{e}+\mathrm{O}_{2} \rightarrow \mathrm{O}+\mathrm{O}+\mathrm{e}$

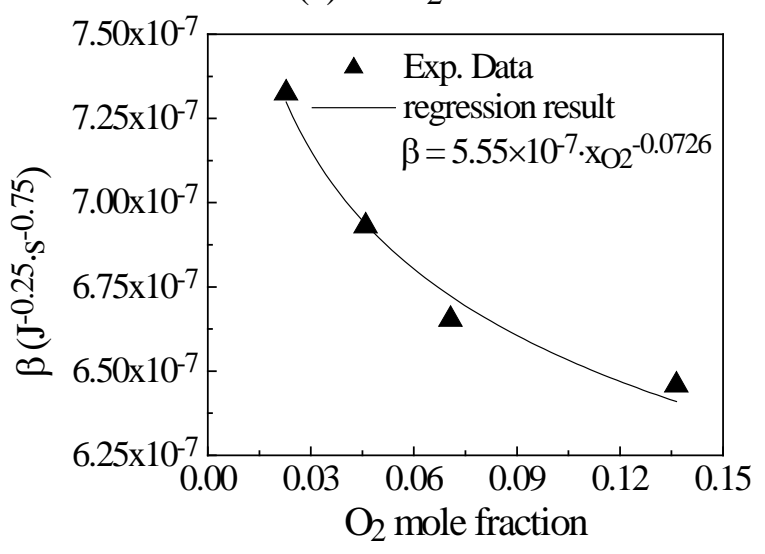

(d) $\mathrm{e}+\mathrm{N}_{2} \rightarrow \mathrm{N}\left({ }^{2} \mathrm{D}\right)+\mathrm{N}\left({ }^{2} \mathrm{D}\right)+\mathrm{e}$

Figure 6. Model parameters as a function of $\mathrm{O}_{2}$ concentration

Model parameter $\alpha$ for electron collision reactions (a); Model parameter $\beta$ for electron collision reaction R37 (b), R38 (c), R39 (d). ( $\mathbf{\square})$ R37, (-) R38, ( $\mathbf{\Delta}$ ) R39, (一) regression results 


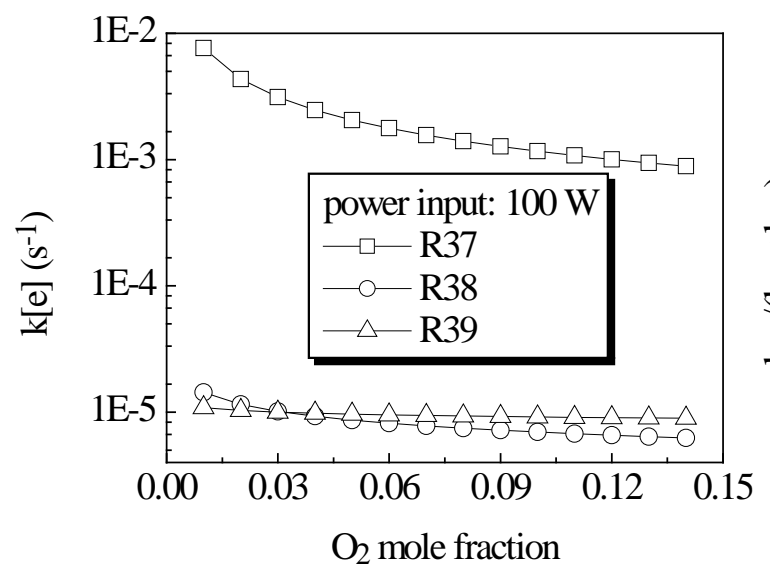

(a)

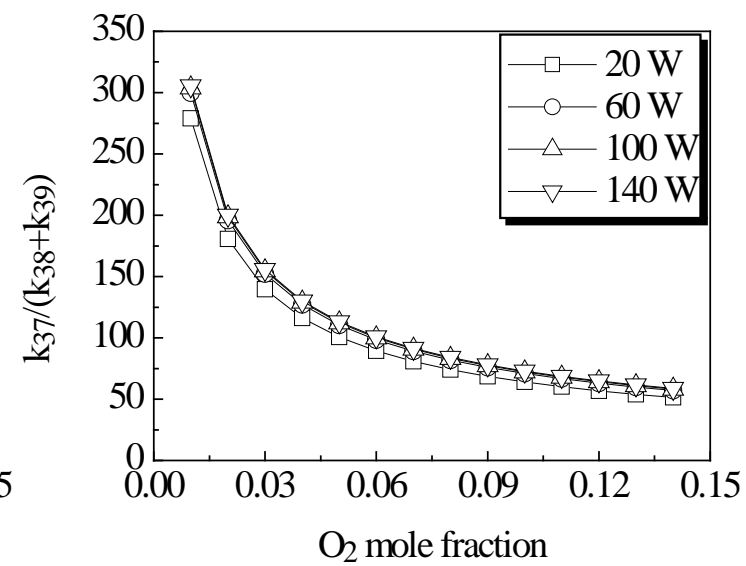

(b)

Figure 7. Rate constants of electron collision reactions R37-R39 as a function of $\mathrm{O}_{2}$ concentration at $100 \mathrm{~W}$ power input (a); Ratio of rate constant of electron collision reaction with $\mathrm{O}_{2}$ and $\mathrm{N}_{2}$ as a function of $\mathrm{O}_{2}$ concentration at different power inputs (b)

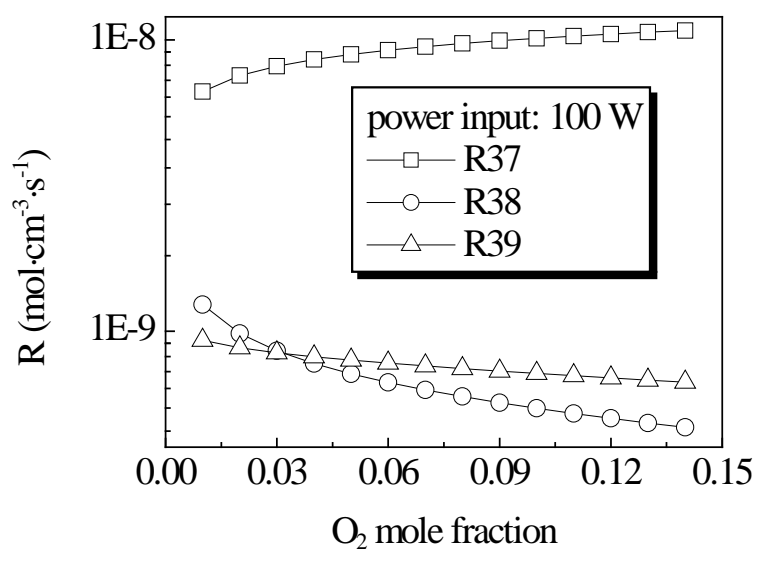

(a)

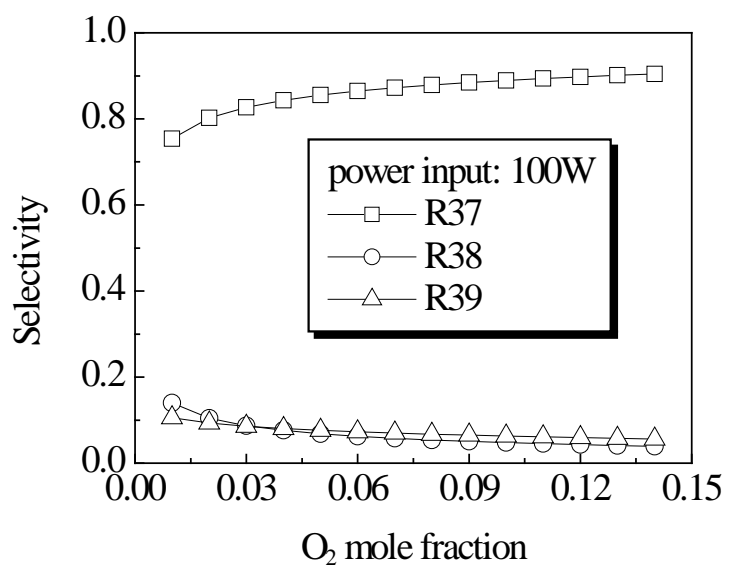

(b)

Figure 8. Rates of electron collision reactions R37-R39 as a function of $\mathrm{O}_{2}$ concentration at 100 W power input (a); Selectivity of electron collision reactions R37-R39 as a function of $\mathrm{O}_{2}$ concentration at $100 \mathrm{~W}$ power input (b) 


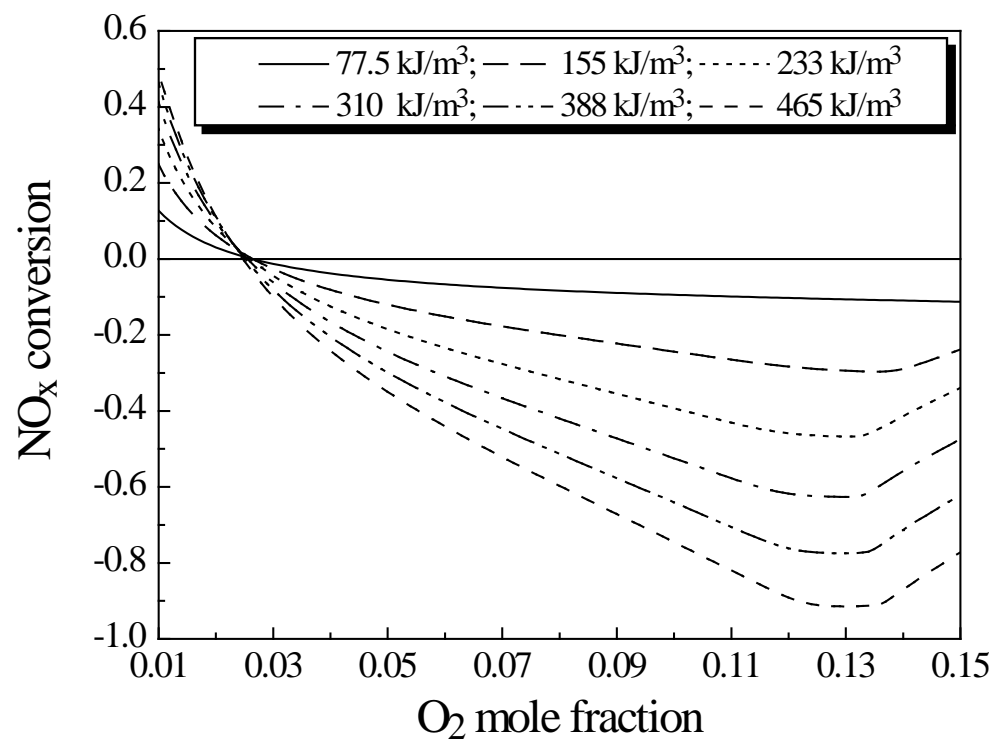

Figure 9. $\mathrm{NO}_{\mathrm{x}}$ conversion as a function of $\mathrm{O}_{2}$ concentration for inlet concentration of $350 \mathrm{ppm}$ $\mathrm{NO}$ at different specific energy input

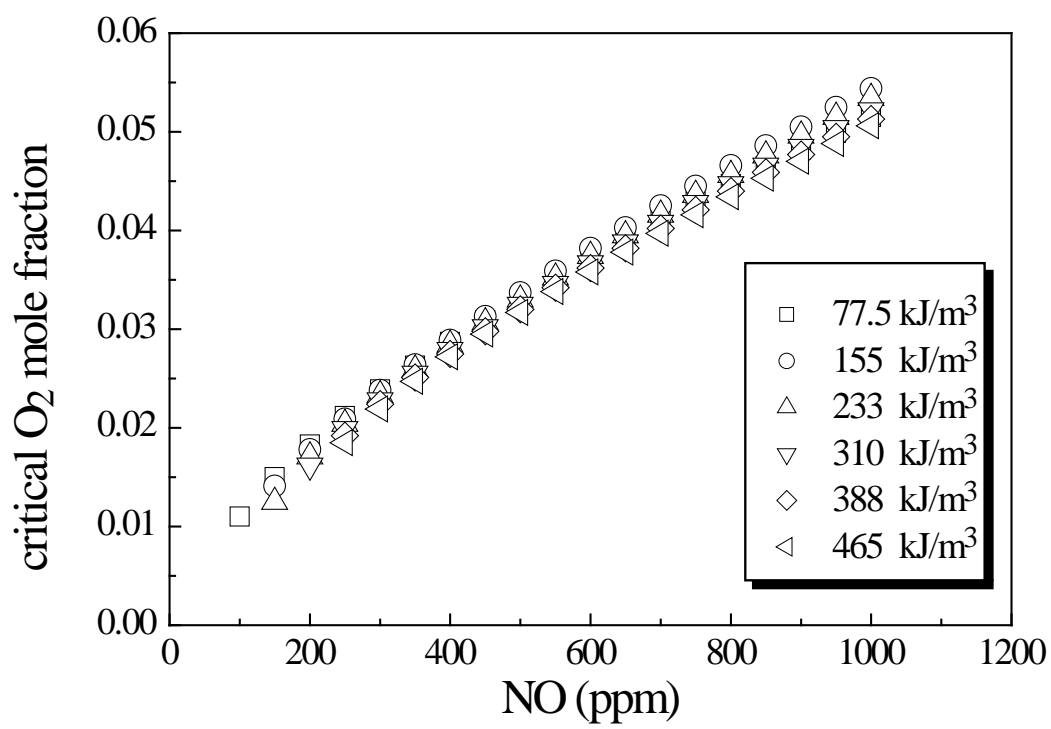

Figure 10. Critical $\mathrm{O}_{2}$ concentration as a function of $\mathrm{NO}$ concentration at different specific energy input 